Portland State University

PDXScholar

\title{
A Comparison of the Effects of Fluoride and Chloride Ions Upon the Activity of Yeast Alcohol Dehydrogenase
}

Ellen J. Hannan

Portland State University

Follow this and additional works at: https://pdxscholar.library.pdx.edu/open_access_etds

Part of the Chemistry Commons

Let us know how access to this document benefits you.

Recommended Citation

Hannan, Ellen J., "A Comparison of the Effects of Fluoride and Chloride Ions Upon the Activity of Yeast Alcohol Dehydrogenase" (1969). Dissertations and Theses. Paper 458.

https://doi.org/10.15760/etd.458

This Thesis is brought to you for free and open access. It has been accepted for inclusion in Dissertations and Theses by an authorized administrator of PDXScholar. Please contact us if we can make this document more accessible: pdxscholar@pdx.edu. 
Portland State University

PDXScholar

$5-1-1969$

\section{A comparison of the effects of fluoride and chloride ions upon the activity of yeast alcohol dehydrogenase}

Ellen J. Hannan

Portland State University

Follow this and additional works at: https://pdxscholar.library.pdx.edu/open_access_etds Let us know how access to this document benefits you.

Recommended Citation

Hannan, Ellen J., "A comparison of the effects of fluoride and chloride ions upon the activity of yeast alcohol dehydrogenase" (1969). Dissertations and Theses. Paper 458.

https://doi.org/10.15760/etd.458

This Thesis is brought to you for free and open access. It has been accepted for inclusion in Dissertations and Theses by an authorized administrator of PDXScholar. Please contact us if we can make this document more accessible: pdxscholar@pdx.edu. 
AN ABSTRACT OF THE THESIS OF Ellen J. Hannan for the Master of Arts in Chemistry presented May 29, 1969.

Title: A Comparison of the Effects of Fluoride and Chloride Ions Upon the Activity of Yeast Alcohol Dehydrogenase.

APPROVED BY MEMBERS OF THE THESIS COMMITTEE:
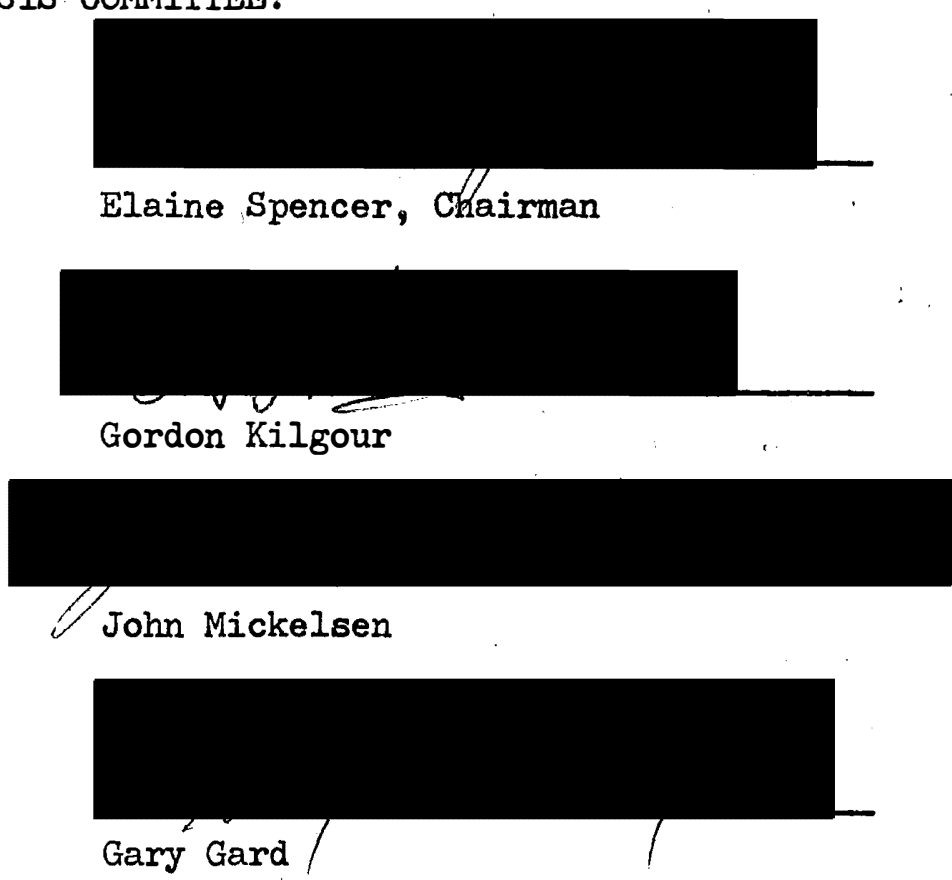

Very little is known about the effect of hydrofluoric acid and of the fluoride ion on enzyme systems. The purpose of this work was to. determine the effect of hydrofluoric acid and of the fluoride ion on the enzyme, yeast alcohol dehydrogenase and to distinguish between the effect of the fluoride ion and of hydrofluoric acid. The rate of the enzyme reaction was followed spectrophotometrically at $340 \mathrm{~m} \mu$ on the Cary 14 Model spectrophotometer according to the method of Racker. The data 
taken from the instrument recordings were plotted on two types of graphs, the Iineweaver-Burk plot and the Hanes plot. Conclusions were drawn from the calculations made on these plots.

Inhibition studies were run using $\mathrm{KCl}, \mathrm{NaCl}, \mathrm{KF}$, and $\mathrm{NaF}$ varying in concentration from 0.001 to $0.12 \mathrm{M}$ at two different pH levels. For the fluoride salts, this gave a concentration of $\mathrm{HF}$ which varied from $8.94 \times 10^{-8}$ to $1.07 \times 10^{-5} \mathrm{M}$ at $\mathrm{pH} 7.5$ and $8.94 \times 10^{-9}$ to $1.07 \times 10^{-6} \mathrm{M}$ at $\mathrm{pH} 8.5$

The fluoride salts showed no greater inhibition than the chloride salts at either $\mathrm{pH}$. Since there is no difference in inhibition between the two types of salts, the inhibition cannot be attributed to the presence of hydrofluoric acid. If the inhibition had been due to hydrofluoric acid, we would have observed a greater inhibition with the fluoride salts than with the chloride salts since hydrochloric acid is 100\% ionized. 
A COMPARISON OF THE EFFECTS OF FLUORIDE AND CHIORIDE IONS UPON THE ACTIVITY OF YEAST ALCOHOL DEHYDROGENASE

$$
\text { by }
$$

EIJEN J. HANNAN

\section{A thesis submitted in partial fulfillment of the requirements for the degree of}

\section{MASTER OF ARTS}

in

CHEMISTRY

Portland State University

1969 
TO THE OFFICE OF GRADUATE STUDIES:

The members of the Committee approve the thesis of Ellen J. Hannan presented May 29, 1969.

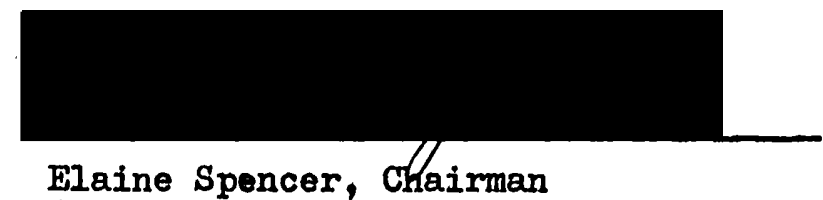

John Mickelsen

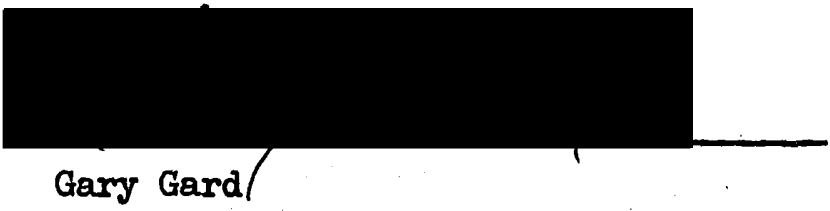

APPROVED:

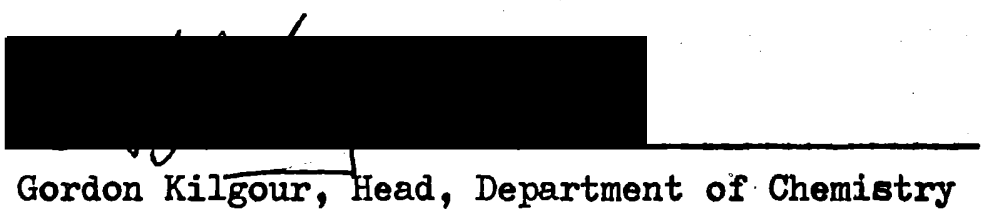

Gean of Graduate Studies David R. Malcolm 
TABIE OF CONTIENTS

PAGE

ACKNOWLEDGEMENTS ....................... iii

IIST OF TABLES ....................... IV

IIST OF FIGURES . . . . . . . . . . . . . . . . v v

HISTORICAL BACKGROUND . . . . . . . . . . . . . 3

METHODS \& EXPERTMENTAL DATA

Materials \& Methods ................ 29

Treatment of Data ....................... 38

Results ................... 59

DISCUSSION . . . . . . . . . . . . . . . 67

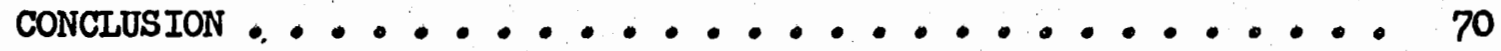

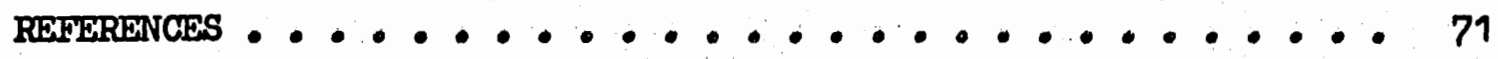




\section{ACKNOWLEDGEMTNIS}

The author wishes to express her sincere gratitude to Dr. Elaine Spencer for her understanding and guidance during this research project; Dr. John Mickelsen for his. help and encouragement; Lou Livingston for his assistance; and Roger Brown for his assistance with the graphs. The author wishes also to express her appreciation to her husband, Richard, for his help and understanding, and to her parents. 


\section{LIST OF TABLES}

TABLE

PAGE

I Amino Acid Composition of YADH ............ 4

II Physical and Chemical Properties of YaDH ......... 5

III' Relative Rates of Oxidation of Alcohols by YADH . . . . 6

IV Michaelis Constants .............. 12

V Inhibition Constants of $N^{\prime}$-alkylnicotinamide and n-alkylammonium Chlorides ........... 16

VI Interaction Constants of Various Inhibitors . . . . 18

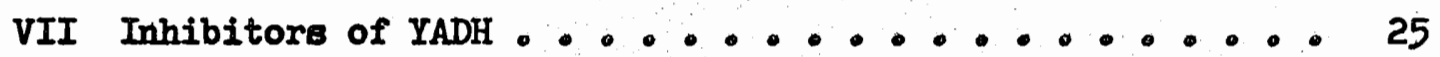


LIST OF FIGURES

FIGURE

PAGE

$1 \mathrm{YADH}$ - Coenzyme complex .............. 13

2 Standard Assay Graph ............. 31

3 Absorption Spectrum of $\mathrm{YADH}$............ 33 .

4 Michaelis Plot, $\mathrm{pH} 8.5$........... 34

5 Michaelis Plot, $\mathrm{pH} 7.5$... . . . . . 35

6 Michaelis Plot, $\mathrm{pH} 8.5$............ 36

7 Michaelis Plot, $\mathrm{pH} 7.5$. . . . . . . 37

8 Iineweaver-Burk Plot, $\mathrm{KCl}, \mathrm{pH} 8.5 . . . . . . .40$

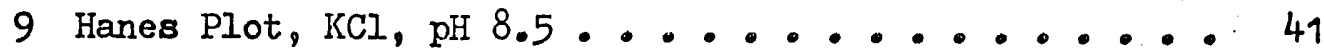

10 Iineweaver-Burk Plot, NaCl, $\mathrm{pH} 8.5 \ldots 42$

11 Iineweaver-Burk Plot, KF, $\mathrm{pH} 8.5 \ldots \ldots 43$

12 Iineweaver-Burk Plot, NaF, pH 8.5 . . . . . 44

13 Iineweaver-Burk Plot, NaCl, pH 8.5 ....... 45

14 Iinewaaver-Burk Plot, KCl, pH 8.5 ....... 46

15 Lineweaver-Burk Plot, NaF, pH 8.5 . . . . . 47

16 Lineweaver-Burk Plot, $\mathrm{KF}, \mathrm{pH} 8.5$........ 48

17 Lineweaver-Burk Plot, NaCl, pH $7.5 \ldots 49$

18 Lineweaver-Burk Plot, KCl, $\mathrm{pH} 7.5$... . . . 50

19 Iineweaver -Burk Plot, KF, pH $7.5 \ldots . . . . . .51$

20 Hanes Plot, KF, $\mathrm{pH} 7.5 \ldots \ldots \ldots 2$

21 Lineweaver-Burk Plot, NaF, pH 7.5 ........ 53 
List of Figures cont'd.

FIGURE

PAGE

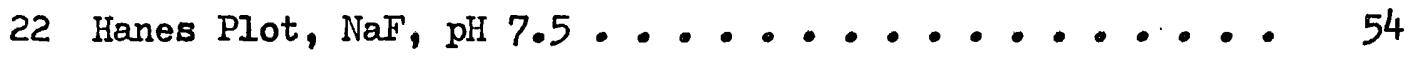

23 Lineweaver-Burk Plot, $\mathrm{NaCl}, \mathrm{pH} 7.5 \ldots . . \ldots 5$

24 Lineweaver-Burk Plot, NaF, pH 7.5 ........ 56

25 Lineweaver-Burk Plot, KF, pH 75. . . . . . . . 57

26 Lineweaver-Burk Plot, KCl, $\mathrm{pH} 7.5 \ldots 58$

$27 \%$ activity vs $\sqrt{\mu}, \mathrm{pH} 8.5 \ldots 60$

$28^{\prime} \%$ activity vs $\sqrt{\mu}, \mathrm{pH} 8.5 \ldots 61$

$29 \%$ activity vs $\sqrt{\mu}, \mathrm{pH} 8.5 \ldots 62$

$30 \%$ activity vs $\sqrt{\mu}, \mathrm{pH} 7.5 \ldots 63$

$31 \%$ activity vs $\sqrt{\mu}, \mathrm{pH} 7.5 \ldots . \ldots 64$ 


\section{INTRODUCTION}

Dehydrogenases constitute one group of a class of enzymes involved in biological oxidation and reduction. They form an essential link to the respiratory chain in both plants and animals. Alcohol dehydrogenase is specific for the oxidation of ethanol or the reduction of acetaldehyde. In the mammalian system, it occurs in the liver and is considered a detoxifying system catalyzing the oxidation of ethanol. In yeast, alcohol dehydrogenase can catalyze either oxidation or reduction depending upon the conditions. Under anaerobic conditions, it will form the ethanol, while under aerobic conditions it will oxidize it. Alcohol dehydrogenase is a typical diphosphopyridine nucleotide-dependent dehydrogenase and conclusions drawn from its study may well apply to other dehydrogenase systems.

Some inorganic fluorine containing compounds are known to have a high toxicity level for rats (1). It has been thought that their toxicity is caused by their hydrolysis to produce HF (1). It is known that these compounds hydrolyze very little in pure water (2), and the amount of HF or fluoride ion produced, therefore, is very small. Since the toxicity levels of fluoride ion and $H F$ for enzyme systems have not been extensively studied, it cannot be determined whether the above explanation for the toxicity of these fluorine compounds is correct or not.

The purpose of this work was to determine the effect of the fluoride ion on an enzyme system and to distinguish between the effect of the fluoride ion and of $\mathrm{HF}$. The chloride salts were studied at the 


\section{HISTORICAL BACKGROUND}

Alcohol dehydrogenase $(A D H)$ is a diphosphopyridine nucleotide linked metalloenzyme catalyzing the reaction:

$$
\mathrm{CH}_{3} \mathrm{CH}_{2} \mathrm{OH}+\mathrm{DPN}^{+} \stackrel{\mathrm{ADH}}{\rightleftharpoons} \mathrm{DPNH}+\mathrm{H}^{+}+\mathrm{CH}_{3} \mathrm{CHO}
$$

Although catalyzing the same reaction, the yeast and the liver enzymes differ widely in their physical properties. This study will be limited to the yeast enzyme.

Work on crude preparations of yeast alcohol dehydrogenase (YADH) was begun in 1935, and in 1937, YADH was purified enough to give a crystalline enzyme. This was first accomplished by Negelein and Wulf using brewer's yeast (3). Their methods have since been modified and improved by Racker (4) and Hayes and Velick (5).

YADH can be obtained relatively easily in pure form and is stable for long periods of time in the dry state or in solution at $\mathrm{pH} 7$ and $0^{\circ} \mathrm{C}(6)$. It has a molecular weight of 150,000 , calculated from sedimentation velocity and diffusion measurements (5), and is composed of 19 amino acids as shown in Table I. YADH requires the presence of the coenzyme nicotinamide adenine dinucleotide $\left(\mathrm{NAD}^{+}\right.$or $\mathrm{DPN}^{+}, \mathrm{NADH}$ or DPNH), for activity. For a more complete list of physical and chemical propexties, consult Table II.

YADH is specific for straight chain primary alcohols. Oxidizing ability decreases with an increase in chain length $(19,20)$. The rate of oxidation decreases in the following order: ethyl alcohol = allyl alcohol, n-propyl alcohol, n-butyl alcohol, n-pentyl alcohol, isopropyl 
TABIE I

AMINO ACID COMPOSTION OF YEAST ADH (7)

\begin{tabular}{|c|c|c|c|}
\hline Amino Acid & moles $/ 150,0$ & 000 g protein & $\mathrm{g} / 100 \mathrm{~g}$ protein \\
\hline $\begin{array}{l}\text { Alanine } \\
\text { Arginine } \\
\text { Aspartic acid } \\
\text { Half-cystine } \\
\text { Cysteine } \\
\text { Cystine } \\
\text { Glutamic acid } \\
\text { Glycine } \\
\text { Histidine } \\
\text { Leucine \& } \\
\text { Isoleucine } \\
\text { Lysine } \\
\text { Methionine } \\
\text { Phenylalanine } \\
\text { Proline } \\
\text { Serine } \\
\text { Threonine } \\
\text { Tryptophan } \\
\text { Tyrosine } \\
\text { Valine } \\
\text { Amide-NH }\end{array}$ & $\begin{array}{r}123.54 \\
31.73 \\
125.38 \\
38.02 \\
36.00 \\
1.00 \\
111.91 \\
150.20 \\
39.63 \\
189.06 \\
93.01 \\
18.08 \\
68.17 \\
50.55 \\
75.43 \\
58.59 \\
27.08 \\
51.05 \\
149.42 \\
73.70\end{array}$ & 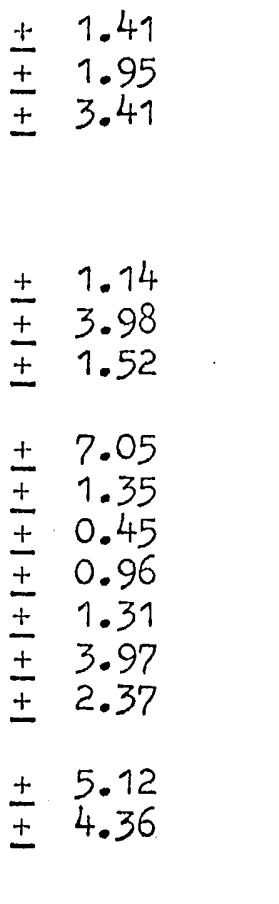 & $\begin{array}{l}5.86 \\
3.31 \\
9.62 \\
2.59 \\
2.48 \\
0.15 \\
9.63 \\
5.72 \\
3.62 \\
14.27 \\
7.95 \\
1.58 \\
6.69 \\
3.27 \\
4.38 \\
3.95 \\
3.36 \\
5.55 \\
9.87 \\
0.79\end{array}$ \\
\hline
\end{tabular}

1 On the supposition that 38.02 moles of half-cystine consists of 36 moles of cysteine (from titration analysis with p-chloromercuribenzoate (8), and 1 mole of cystine (7). 
TABLE II

PHYSICAI AND CHEMICAI PROPERTIES OF YADH

\begin{tabular}{|c|c|c|}
\hline Property & Value & Reference \\
\hline $\begin{array}{l}\text { Molecular weight } \\
\text { Absorbance ratio } 280 / 260 \\
\mathrm{E}_{280} \\
\mathrm{~S}_{20} \\
\mathrm{D}_{20} \\
\overline{\mathrm{V}} \\
\mathrm{f} / \mathrm{f}_{\text {o }} \\
\text { iso-electric pH } \\
\text { pH optimum } \\
\text { Dispersion constant }\end{array}$ & $\begin{array}{l}150,000 \mathrm{~g} \\
1.82 \\
1.89 \times 10^{-5} \\
6.72 \times 10^{-13} \\
7.61 \times 10^{-13} \\
7.20 \times 10^{-13} \\
(4.70 \pm 0.03) \times 10^{-7} \mathrm{~cm}^{2} \text { sec }^{-1} \\
0.769 \mathrm{ml} / \mathrm{g} \\
1.27 \\
5.4 \\
8.5 \\
262 \mathrm{~m} \mu \text { in } \mathrm{M} / 15 \text { phosphate buffer, } \\
223 \mathrm{m \mu} \text { in } 6 \mathrm{M} \mathrm{urea,} \mathrm{pH} 7.6 \\
248.4 \pm 5 \mathrm{m \mu} \mathrm{pH} 8.0 \\
52.8 \% \\
6.96 \% \\
16.54 \% \\
1.21 \% \\
0.015 \% \\
0.0027 \% \\
0 \% \\
4-5 \text { atoms }\end{array}$ & $\begin{array}{l}5 \\
5 \\
5,9 \\
5 \\
10,11 \\
12 \\
5 \\
5 \\
5 \\
5,9 \\
9 \\
15,13 \\
14 \\
13 \\
14 \\
16 \\
\end{array}$ \\
\hline
\end{tabular}


alcohol (19). Three factors appear to determine the specificity of the enzyme: 1) the nucleophilic character of the alcohol; 2) the molecular dimensions of the alcohol; and 3) the orientation of the alcohol molecule. Table III gives the relative rates for various alcohols and their derivatives.

TABIE III

RELATIVE RATES OF OXIDATION OF ALCOHOLS BY YADH

\begin{tabular}{|c|c|c|c|c|}
\hline Alcohol & $\begin{array}{c}\text { Relative } \\
\text { (19) }\end{array}$ & $\begin{array}{l}\text { Rates } \\
(20)\end{array}$ & Alcohol & $\begin{array}{c}\text { Relative Rates } \\
(20)\end{array}$ \\
\hline $\begin{array}{l}\text { methyl } \\
\text { ethyl } \\
\text { n-propyl } \\
\text { allyl } \\
\text { isopropyl } \\
\text { n-butyl } \\
\text { isobutyl } \\
\text { sec-butyl } \\
\text { n-pentyl } \\
\text { isopentyl } \\
\text { 3-hexanol } \\
\text { t-butyl }\end{array}$ & $\begin{array}{c}0 \\
100 \\
36 \\
100 \\
6.6 \\
17.5 \\
0 \\
0 \\
12.5\end{array}$ & $\begin{array}{r}8 \\
1000\end{array}$ & $\begin{array}{l}\text { ethylene glycol } \\
\text { glycerol } \\
\text { erythritol } \\
\text { L-arabitol } \\
\text { 2-aminoethanol } \\
\text { dimethylamino- } \\
\text { ethanol } \\
\text { diethylamino- } \\
\text { ethanol } \\
\text { 2-chloroethanol } \\
\text { D (-) lactic acid } \\
\text { glycolic acid } \\
\text { DL - - -hydroxy } \\
\text { butyric acid }\end{array}$ & $\begin{array}{c}1.2 \\
7 \\
2 \\
1.5 \\
22 \\
0 \\
0 \\
8 \\
3 \\
17\end{array}$ \\
\hline
\end{tabular}

The above studies by Barron and Levine (19) were done using a reaction mixture containing $4 \mu g$ of enzyme. When the enzyme concentration was increased to $88 \mu \mathrm{g}$, they were able to detect the oxidation of isobutyl alcohol, methyl alcohol, ethylene glycol, and sec-butyl alcohol. In order to detect the oxidation of octyl alcohol, and glycerol, they had to increase the enzyme concentration to $220^{\circ} \mu \mathrm{g}$. Even at this high concentration of enzyme, they were unable to detect a measurable rate of oxidation of mannitol. 
Zinc and sulfhydryl groups are both essential for the activity of YADH. Essential groups may play an active role in the binding of the substrate or the coenzyme, or they may be responsible for the quaternary structure of the enzyme, or for electronic effects during catalysis. Zinc, which is known to hold the four monomolecular units together forming the active enzyme (21), may also be necessary for the binding of the coenzyme.

Kagi and Vallee (21) studied the role of the zinc in the quaternary structure of the enzyme using chelating agents. When YADH is exposed to chelating agents, it dissociates into four equal monomeric units. The loss of activity is proportional to this dissociation and to the loss of zinc. One of the more commonly used chelating agents is 1,10-phenanthroline (OP). OP shows two types of inhibition depending upon the reaction conditions.

$O P$ shows an instantaneous reversible inhibition (22) and a time dependent irreversible inhibition (23). $\mathrm{DPN}^{+}$will protect the enzyme against the first type of inhibition, but when the enzyme is incubated with $\mathrm{OP}$ in the absence of $\mathrm{DPN}^{+}$, the second type of inhibition is observed. Addition of $\mathrm{DPN}^{+}$after incubation of $\mathrm{OP}$ with the enzyme has no effect upon the inhibition. $\mathrm{DPN}^{+}$can compete with $\mathrm{OP}$ for the active site of the enzyme, but $\mathrm{DPN}^{+}$cannot displace $\mathrm{OP}$ once it is bound. The substrates show no protective effect for either type of inhibition. $\mathrm{DPN}^{+}$. can protect against the first type of inhibition because the structure of the enzyme has not yet changed. When the enzyme and OP are allowed to be in close contact for an extended period of time, a second mole of $O P$ will bind to the zinc and thus change the structure of the 
enzyme. In this way, the enzyme is inactivated irreversibly.

Since the substrates have no effect on the inhibition, it is assumed that if the zinc is involved in the binding, it is the binding of the coenzyme. It may be that the zinc is close to the binding site of the coenzyme, and the binding of the OP sterically blocks the $\mathrm{DPN}^{+}$ binding site. The work of Kagi and Vallee (21) did not demonstrate conclusively that the zinc is involved in the active site.

Using the emission spectrograph, Vallee and Hoch (17) determined the zinc content of $\mathrm{YADH}$ to be four atoms of zinc per mole of enzyme. Pfleider, Jeckel, and Wieland, as quoted by Wallenfels and others (18), found the zinc content to be around five atoms per mole of enzyme using the dithizone method. This is in agreement with the work of Wallenfels and coworkers who used the X-ray fluorescence method (24).

The sulfhydryl content of $\mathrm{YADH}$ has been determined by many investigators with many variations. The number of sulfhydryl groups seems to vary with the enzyme preparation and with the method of determination used. Wallenfels and Sund (8) showed that there was a linear relationship between the activity of the enzyme preparation and the number of free sulfhydryl groups. Using the optical method of Boyer (25), which uses $\mathrm{p}$-chloromercuribenzoate (PCMB) as the sulfhydryl reagent, Wallenfels and Sund (8) found the number of sulfhydryl groups to vary from 4 to 36 . PCMB reacts with the sulfhydryl groups of the enzyme to form the mercaptide. The optical absorption of PCMB is then increased. Boyer found that the increase in the neighborhood of 250 to $255 \mathrm{~m} \mu$ is linearly related to the number of sulfhydryl groups, therefore, the number of sulfhydryl groups can be determined from the increased absorption. Excess 
PCMB does not add appreciably to this increased absorbance.

When Wallenfels and Sund (8) titrated the enzyme with silver nitrate and followed the reaction amperometrically, they found an average of 21 free sulfhydryl groups. This is close to the values found by Barron and Levine (19). Using the same method, Barron and Levine found YADH to contain 18-19 moles of sulfhydryl groups per mole of enzyme. Hoch and Vallee (26) arrived at a value of 25 moles of free sulfhydryl groups per molecule using the silver nitrate amperometric method.

Hoch and Vallee also used PCMB and found a value of 16 free sulfhydryl groups. Barron and Levine titrated the enzyme with iodosobenzoate and determined a value of 22.5 moles of free sulfhydryl groups per mole of enzyme.

In some proteins, all the sulfhydryl groups are necessary for activity. YADH is believed to be a member of this group. Barron and Levine (19) showed that inhibition occurred after the addition of enough PCMB to titrate $6.3 \%$ of the sulfhydryl groups and was not complete until all the sulfhydryl groups had been titrated. The exact role of the sulfhydryl groups cannot be determined from the above information. To show that the sulfhydryl groups are involved in the active site more work had to be done.

The next step was the titration of the sulfhydryl groups in the presence of both coenzyme and substrate. Barron and Levine (19) and Wallenfels and coworkers (18) found the number of free sulfhydryl groups to decrease in the presence of the coenzyme and substrate. Hoch and Vallee (26), however, did not find this to be true using both the PCMB method and the silver nitrate method. 
Whitehead and Rabin (27) found iodoacetamide to be a very specific sulfhydryl reagent. The number of free sulfhydryl groups was determined before the addition of iodoacetamide and then again after the addition of iodoacetamide. The number of sulfhydryl groups was found to be consistently reduced by four. YADH had already been shown to have four active sites (5). It was, therefore, assumed that this represented one sulfhydryl group per active site. YADH lost $95 \%$ of its activity after reaction with four moles of iodoacetamide. In view of the previous work by Barron and Levine (19), PCMB must not act directly on the sulfhydryl groups in the active sites. PCMB appears to show no preference for the sulfhydryl groups, whereas iodoacetamide appears to act immediately upon the sulfhydryl groups in the active sites.

Iodoacetic acid appears to have the same quality of specificity as iodoacetamide. Harris (28) made use of this fact and used iodoacetic-1 $\left({ }^{14} \mathrm{C}\right)$ acid to determine the partial amino acid sequence of the active site. After inhibiting the enzyme with iodoacetic-1 $\left({ }^{14} \mathrm{C}\right)$ acid, he digested the carboxymethylated enzyme with trypsin. The radioactive fragments were separated from the rest of the fragments and subjected to amino acid analysis. Another sample of the radioactive fragment was partially hydrolyzed with chymotrypsin. This hydrolysis gave five peptides which were further degraded. Putting all his information together, mainly from overlapping fragments, he obtained the following sequence

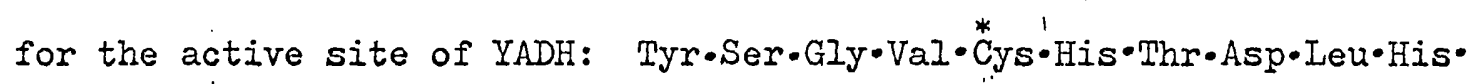

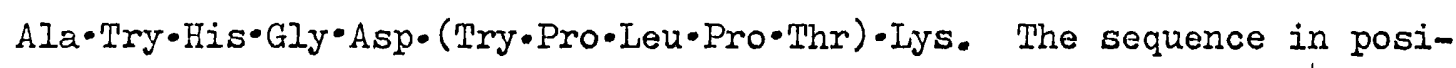
tions 16-20 could not be rigorously established by his methods. Iodoacetic acid and iodoacetamide do not cause denaturation as 
they inactivate. Both $\mathrm{DPN}^{+}$and DPNH protected against inactivation, while ethanol had no effect, and acetaldehyde enhanced inactivation. From this, one would tend to conclude that the coenzyme is bound at or near the sulfhydryl groups.

Hayes and Velick (5) first studied the binding of the coenzyme, $\mathrm{DPN}^{+}$, to YADH by means of the ultracentrifuge. They found that four moles of coenzyme were bound per mole of enzyme. They also found that there was competition between the reduced and oxidized forms of the coenzyme, with DPNH having a greater affinity for the enzyme as can be seen by looking at the Michaelis constants in Table IV.

Van Eys, Kaplan, and Ciotti $(34,35,36)$ have studied extensively the binding of the coenzyme. They have, in fact, proposed a mechanism for the binding. The mechanism involves binding of the coenzyme in three places on the enzyme: 1) the adenine group to a sulfhydryl group of the enzyme; 2) the pyrophosphate group to the zinc; and 3) the pyridinium nitrogen to a second sulfhydryl group (34). See Figure 1.

Their proposed binding mechanism was based on inhibition studies of pyridine derivatives and the work of Barron and Levine (19) on the sulfhydryl groups. Van Eys and coworkers used three types of pyridine derivatives: 1) free pyridine bases, 2) N-methylpyridinium salts, and 3) analogues of $\mathrm{DPN}^{+}$.

Inhibition by the free pyridine bases was found to be proportional to the $\mathrm{pK}_{\mathrm{a}}$ of the ring nitrogen. This led to the choice of the N-methylpyridinium salts as inhibitors. The inhibitory action was greater the stronger the electronegativity of the side chain. Van Eys and coworkers found that the inhibiting species was actually the pyri- 
TABIE IV

MICHAELIS CONSTANTS

\begin{tabular}{|c|c|c|c|}
\hline & $K_{M}$ & Conditions & References \\
\hline $\mathrm{ADH} \cdot \mathrm{EtOH}$ & $\begin{array}{l}0.10 \\
0.074 \\
1.8 \times 10^{-2} \\
1.3 \times 10^{-2} \\
1.4 \times 10^{-2} \\
1.6 \times 10^{-2} \\
2.1 \times 10^{-2}\end{array}$ & $\begin{array}{lll}23^{\circ} \mathrm{C}, & \mathrm{pH} & 6.0 \\
23^{\circ} \mathrm{C}, & \mathrm{pH} & 7.15 \\
26^{\circ} \mathrm{C} & \\
25^{\circ} \mathrm{C}, \mathrm{pH} & 8.45 \\
\mathrm{R} . \mathrm{T}, & \mathrm{pH} & 8.2 \\
20^{\circ} \mathrm{C}, & \mathrm{pH} & 7.7 \\
25^{\circ} \mathrm{C}, \mathrm{pH} & 9.3\end{array}$ & $\begin{array}{r}29 \\
29 \\
5 \\
30 \\
31 \\
32 \\
33\end{array}$ \\
\hline $\mathrm{ADH}{ }^{\bullet} \mathrm{DPN}^{+}$ & $\begin{array}{l}2.6 \times 10^{-4} \\
1.7 \times 10^{-4}-4 \\
1.6 \times 10^{-4} \\
2.3 \times 10^{-4}\end{array}$ & $\begin{array}{l}\text { dissociation } \\
\text { constant } \\
26^{8} \mathrm{C} \\
23^{\circ} \mathrm{C}, \mathrm{pH} 6.0 \\
23^{\circ} \mathrm{C}, \mathrm{pH} 7.15\end{array}$ & $\begin{array}{r}5 \\
5 \\
29 \\
29\end{array}$ \\
\hline $\mathrm{ADH} \cdot \mathrm{Acet}$ & $\begin{array}{l}0.54 \times 10^{-4} . \\
1.44 \times 10^{-4} \\
10^{-4} \\
1.8 \times 10^{-4}\end{array}$ & $\begin{array}{l}23^{\circ} \mathrm{C}, \mathrm{pH} 6.0 \\
23^{\circ} \mathrm{C}, \mathrm{pH} 7.15 \\
26^{\circ} \mathrm{C} \\
\text { dissociation } \\
\text { constant }\end{array}$ & $\begin{array}{r}29 \\
29 \\
5 \\
5\end{array}$ \\
\hline $\mathrm{ADH} \cdot \mathrm{DPNH}$ & $\begin{array}{l}0.43 \times 10^{-5} \\
1.0 \times 10^{-5} \\
2.3 \times 10^{-5} \\
1.3 \times 10^{-5}\end{array}$ & $\begin{array}{l}23^{\circ} \mathrm{C}, \mathrm{pH} 6.0 \\
23{ }^{\circ} \mathrm{C}, \mathrm{pH} 7.15 \\
26^{\circ} \mathrm{C} \\
\text { dissociation } \\
\text { constant }\end{array}$ & $\begin{array}{r}29 \\
29 \\
5 \\
5\end{array}$ \\
\hline
\end{tabular}



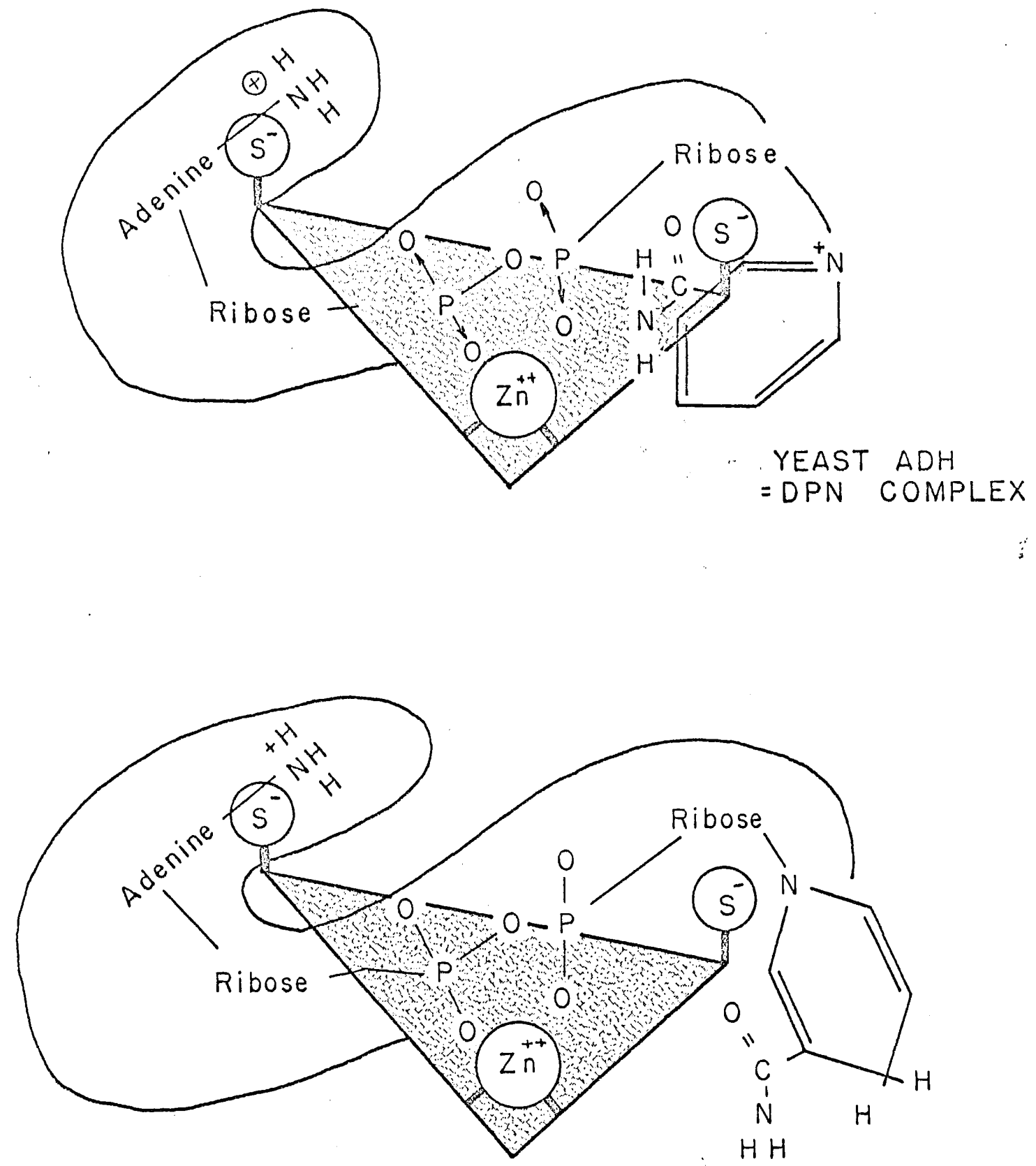

Figure I YADH-COENZYME COMPLEX

$$
\begin{aligned}
& \text { YEAST ADH } \\
= & \text { DPNH COMPLEX }
\end{aligned}
$$


dinium ion.

$\beta$-Picoline was the only analogue of $\mathrm{DPN}^{+}$which inhibited $\mathrm{DPN}^{+}$ reduction. It was found to be competitive with respect to $\mathrm{DPN}^{+}$. It had little effect on the reverse reaction, while the pyridine analogue had no effect on the forward reaction, but inhibited strongly the reduction of acetaldehyde.

From the above information, Van Eys and coworkers were able to conclude that there was a difference in the binding of $\mathrm{DPN}^{+}$and DPNH. Since pyridinium ions inhibit the forward reaction, a negatively charged group must be important in the binding of $\mathrm{DPN}^{+}$but not in the binding of DPNH. Combining this information with that of Barron and Levine (19) who showed a decrease of eight sulfhydryl groups, they proposed the binding of the coenzyme to the enzyme as shown in Figure 1.

The pyrophosphate group is proposed to be more important in the binding of DPNH than in the binding of $\mathrm{DPN}^{+}$, and the pyridinium ring nitrogen is more important in the binding of $\mathrm{DPN}^{+}$.

The mechanism of the coenzyme being bound at at least two sites on the enzyme is in agreement with the work of Anderson and his coworkers $(37,38,39,40,41)$. Anderson's work was directed more towards describing the type of interactions that take place at the binding site than trying to show exactly what groups are involved in the binding.

According to Anderson, there are two different sites involved in the binding of the coenzyme to the enzyme. One is referred to as the "pyridinium ring" region, and the other is the "adenine" region. The "pyridinium ring" region is near a relatively non-polar area where hydrophobic interactions enhance binding. 
To interact with the "pyridinium ring" region, they used N-alkylnicotinamide chlorides, which are structurally related to the coenzyme, and n-alkylammonium chlorides which are not related to the coenzyme. From Table V, it can be seen that the inhibition increases with an increase in the chain length of the substituent. Adenosine diphosphate (ADP) and adenosine diphosphoribose (ADPR) were used as inhibitors of the adenine region (41). In later studies, adenylic acid (AMP) was also used.

To show that these two binding sites are independent, Anderson and Fonda (42) did some multiple inhibition studies using the N-alkylnicotinamide (butyl to heptyl inclusive) and n-alkylammonium chlorides ; (butyl to octyl inclusive) and AMP and ADPR. The adenine inhibitors inhibited both the oxidation of ethanol and the reduction of acetaldehyde, but the pyridinium inhibitors inhibited only the oxidation of ethanol.

In multiple inhibition studies, the ratio of the initial velocity without inhibitor to the initial velocity with inhibitor is plotted versus the concentration of this inhibitor. The concentration of the second inhibitor is kept constant. This is done for different concentrations of the second inhibitor giving a family of lines. If the two inhibitors are mutually independent, the lines will converge. The point of intersection is equal to $\alpha K_{I} \cdot K_{I}$ is the inhibition constant for the first inhibitor and $\alpha$ is the interaction constant for the pair of inhibitors. It is usually less than one. If the two inhibitors are mutually exclusive, the series of lines will be parallel with an interaction constant of infinity. Some typical examples of interaction con- 


\section{TABLE V}

INHIBITION CONSTANTS OF N'-ALKYINICOTINAMIDE AND n-ALKYLIAMMONIUM CHLORIDES

\begin{tabular}{|c|c|c|c|c|}
\hline Alkyl sroup & $\frac{N^{\prime}-a I k y l n i c o}{K_{i}}$ & $\begin{array}{l}\text { inamide }(37,39) \\
\text { Comments }\end{array}$ & $\begin{array}{c}n-a / k y l a m m o n i u m \\
K_{i}\end{array}$ & $\begin{array}{c}\text { chloride }(38) \\
\text { Comments }\end{array}$ \\
\hline $\begin{array}{l}\text { methyl } \\
\text { propyl } \\
\text { butyl } \\
\text { pentyl } \\
\text { hexyl } \\
\text { heptyl } \\
\text { octyl } \\
\text { nonyl } \\
\text { decyl } \\
\text { undecyl } \\
\text { dodecyl } \\
\text { benzyl } \\
\text { lauryl }\end{array}$ & $\begin{array}{l}6.51 \times 10^{-2} \\
5.72 \times 10^{-2} \\
4.62 \times 10^{-2} \\
2.85 \times 10^{-2} \\
1.61 \times 10^{-2} \\
8.86 \times 10^{-3} \\
4.85 \times 10^{-3} \\
2.24 \times 10^{-3} \\
1.33 \times 10^{-3} \\
7.63 \times 10^{-4} \\
4.25 \times 10^{-4} \\
1.18 \times 10^{-2}\end{array}$ & $\begin{array}{l}\text { competitive with } \\
\text { respect to. DPN } \\
\text { and non-competi- } \\
\text { tive with respect } \\
\text { to } \\
\text { ethanol } \\
\text { mixed inhibition } \\
\text { (octyl through } \\
\text { dodecyl) } \\
\text { comp. with respect to } \mathrm{DPN}^{+} \\
\text {mixed }\end{array}$ & $\begin{array}{l}8.74 \times 10^{-2} \\
3.44 \times 10^{-2} \\
1.61 \times 10^{-2} \\
8.9 \times 10^{-3} \\
2.88 \times 10^{-3}\end{array}$ & $\begin{array}{l}\text { inhibit both the oxidation } \\
\text { of EtOH and the reduction } \\
\text { of acetaldehyde. For the } \\
\text { reduction, a higher concen- } \\
\text { tration is necessary. It } \\
\text { is more complex. Iow con- } \\
\text { centrations activate. }\end{array}$ \\
\hline
\end{tabular}


stants are given in Table VI.

From the interaction constants, it can be seen that the two types of inhibitors are independent of each other, supporting the two site mechanism. As a matter of fact, there seems to be a slight enhancement between the adenine inhibitors and the N-alkylnicotinamide chlorides. The binding of DPNH is independent of the binding of the N-alkylnicotinamide chlorides, but it is not independent of the adenine binding site.

There is still the question of the pyrophosphate group. Van Eys, Ciotti and Kaplan (35) have postulated that it is bound to the zinc because the pyrophosphate group. shows activation at low concentrations and inhibition at high concentrations, the same as OP. Anderson and Reynolds (44) showed that the $K_{I}$ with respect to $D_{P N}^{+}$for ADP was close to the $K_{I}$ for AMP and that it was the adenine group rather than the phosphate group which was involved in the binding. The $\mathrm{K}_{\mathrm{I}}$ 's with respect to DPNH were quite different and they concluded that the pyrophosphate group may be more important for the binding of the DPNH. This agrees with the work of Van Eys, Ciotti and Kaplan.

There haven't been many studies on the binding of the substrate to the coenzyme. It is known that only one molecule of ethanol is oxidized at a time even though there are four molecules of coenzyme bound (20). Barron and Levine (19) did some work with the binding of the substrate using substituted derivatives of ethanol.

Barron and Levine (19) postulated that the terminal methyl group was involved in binding to the active center. Substitution of an amine group and an acyl group for one of the hydrogens of the methyl group 
TABIE VI

INIEERACTION CONSTANTS OF VARIOUS INHIBITORS

\begin{tabular}{|c|c|c|c|c|c|}
\hline $\begin{array}{l}\text { n-Alkylammonium } \\
\text { chloride (42) }\end{array}$ & AMP & \multicolumn{2}{|c|}{ ADPR } & \multicolumn{2}{|r|}{ DPNH } \\
\hline $\begin{array}{l}\text { Butyl } \\
\text { Pentyl } \\
\text { Hexyl } \\
\text { Heptyl } \\
\text { Octyl }\end{array}$ & \multirow[t]{3}{*}{$\begin{array}{l}0.75 \\
0.73 \\
0.76 \\
0.74 \\
0.76\end{array}$} & \multicolumn{2}{|c|}{$\begin{array}{l}1.15 \\
0.83 \\
0.73 \\
0.67 \\
0.66\end{array}$} & \multirow{3}{*}{\multicolumn{2}{|c|}{$\begin{array}{l}1.03 \\
0.67 \\
0.33 \\
0.33\end{array}$}} \\
\hline $\begin{array}{l}\text { N-Alkylnicotinamide } \\
\text { chloride }(42)\end{array}$ & & \multirow{2}{*}{\multicolumn{2}{|c|}{$\begin{array}{l}0.52 \\
0.37 \\
0.33 \\
0.25\end{array}$}} & & \\
\hline $\begin{array}{l}\text { Butyl } \\
\text { Pentyl } \\
\text { Hexyl } \\
\text { Heptyl }\end{array}$ & & & & & \\
\hline Inhibitor \#2 (43) & Adenosine & AMP & ADP & ADPR & $\begin{array}{l}\text { N-methylnico- } \\
\text { tinamide chlor } \\
\text { ide }\end{array}$ \\
\hline $\begin{array}{l}\text { 1,10-phenanthroline } \\
\text { 1,5-phenanthroline } \\
\text { 2,9-dimethyl-1,10- } \\
\text { phenanthroline } \\
\text { 7,8-benzoquinoline } \\
\text { 5,6-benzoquinoline } \\
\text { quinoline } \\
\text { adenosine } \\
\text { adenosine diphosphate } \\
\text { adenosine diphosphate } \\
\text { ribose } \\
\text { adenylic acid }\end{array}$ & $\begin{array}{l}\infty \\
\infty \\
\infty \\
\infty \\
\infty \\
1.0 \\
\infty \\
\infty \\
\infty\end{array}$ & $\begin{array}{l}\infty \\
\infty \\
\infty \\
\infty \\
\infty \\
1.0 \\
\infty \\
\infty \\
\infty \\
-\end{array}$ & $\begin{array}{l}\infty \\
\infty \\
\infty \\
\infty \\
\infty \\
1.0 \\
\infty \\
\infty \\
\infty\end{array}$ & $\begin{array}{l}\infty \\
\infty \\
\infty \\
\infty \\
1.7 \\
\infty \\
\infty \\
- \\
\infty\end{array}$ & $\begin{array}{l}\infty \\
\infty \\
\infty \\
\infty \\
\infty \\
1.0 \\
\infty \\
1.8 \\
-\end{array}$ \\
\hline
\end{tabular}


produced a loss of ability to reduce $\mathrm{DPN}^{+}$. The substituted derivatives of ethanol did not inhibit the rate of oxidation of ethanol, however, when they were present in a concentration five times as great as the concentration of ethanol. Fluoroethanol and chloroethanol caused complete inhibition when present in this same ration of $5: 1$, and fluoroethanol caused $40 \%$ inhibition when present in the ratio of $0.33: 1$. Substitution of $\mathrm{OH}$ with $\mathrm{CN}, \mathrm{NH}_{2}$, or $\mathrm{COOH}$ had no effect. Westheimer (45) also postulates that the methyl group is bound to the enzyme.

Most of the rest of the work that has been done involving the substrate has involved kinetic studies which have been designed to determine whether the binding between the coenzyme, the substrate, and the enzyme is ordered or random. Recent nmr studies show evidence of an ordered binding.

The nmr studies are based on the line widths in the spectra. The line widths are sensitive to the degree and type of molecular motions occurring in the sample. An increase in the width of the line is associated with a decrease in molecular motion, particularly rotational. This increase in line width is observed when a small molecule is bound to a large molecule.

There are no observable differences between the spectrum of ethanol and the spectrum of ethanol and enzyme $(46,47)$. It may be that the substrate is bound to the enzyme but not in a stereospecific manner as it is in the presence of the coenzyme. There was' an observed change in the spectrum when $\mathrm{DPN}^{+}$was added, with slight broadening of the lines and a decrease in intensity. Without further study, Hollis and his coworkers are not willing to conclude that this shows binding of ethanol in 
the presence of $\mathrm{DPN}^{+}$. They think that it may be due to a preferential binding of DPNH and acetaldehyde.

They did show, however, that there did exist a binary complex between the coenzyme and the enzyme. They found a greater interaction between the adenine protons and the enzyme than between the nicotinamide protons and the enzyme. Earlier workers (48) had shown the interaction of the pyridine ring and the enzyme. The nmr should be helpful in further studies on the binding of the coenzyme and substrate and the binding of the inhibitors.

Up until this time, the only conclusions on a random versus ordered mechanism have been based on kinetic studies. The early kinetic studies on YADH were done by Negelein and Wulff (49) and Hayes and Velick (5). YADH was shown to follow a rate equation of the general form of the Michaelis-Menten equation:

$$
v=\frac{v(c)(s)}{\left(\mathrm{K}_{\mathrm{s}}+(\mathrm{S})\right)\left(\mathrm{K}_{\mathrm{c}}+(\mathrm{C}) \mathrm{T}\right.}
$$

where $\mathrm{V}$ is the maximal velocity, (C) is the concentration of the coenzyme, (S) is the concentration of the substrate, $\mathrm{K}_{B}$ is the Michaelis constant for the substrate; and $\mathrm{K}_{c}$ is the Michaelis constant for the coenzyme.

All the work that has been done supports a ternary complex mechanism $(50,51,52,53,54)$. Hayes and Velick (5) assumed the formation of binary complexes between the enzyme and the coenzyme, but they did not consider the binary complexes with the substrate. Dalziel (55) concludes that there is no direct evidence for the existence of the binary complexes with the substrate, but Silverstein and Boyer (53) 
conclude that they exist.

Silverstein and Boyer's conclusion is based on the existence of an equilibrium between the ethanol and acetaldehyde which reaches a peak and then drops with an increase in the concentration of the coenzyme. The interconversion of the coenzyme stays essentially constant, and is quite considerable even in the presence of high substrate concentrations.

Silverstein and Boyer proposed a random binding mechanism involving all four binary complexes and the two ternary complexes. Up until this time, the interconversion of the ternary complexes was believed to be the slow step. They showed that the dissociation of the coenzyme from the ternary complex was the slow step, and not the interconversion of the termary complex.

All the above work is based on initial velocity studies or equilibrium studies. Wratten and Cleland (52) using product inhibition studies showed that $Y A D H$ follows an ordered $B i$ Bi mechanism. The rate equation for this mechanism was derived by Cleland (56). Several terms in this rate equation will drop out if a rapid equilibrium exists where the interconversion of the ternary complex is rate limiting. They will also drop out if the ternary complex is essentially nonexistent. Wratten and Cleland showed that these terms did not drop out. There is an existence of a ternary complex, but it is not rate-limiting.

In their product inhibition studies, they. found both ethanol and acetaldehyde to be noncompetitive inhibitors with respect to each other, and DPNH was a competitive inhibitor with respect to $\mathrm{DPN}^{+}$. This is in agreement with the work of Hayes and Velick (5). 
This recent work of Wratten and Cleland together with the nmr studies of Hollis favor ordered binding of the coenzyme and the substrate with the coenzyme binding first. Both of them must be bound in order for the reaction to take place.

The reaction catalyzed by YADH is stereospecific for both the coenzyme and the substrate. The transfer of hydrogen is from one side of the alpha carbon of ethanol to one side of the pyridine ring at the 4 position $(45,57,58)$. This is a direct transfer from the substrate to the coenzyme involving no exchange with the solvent $(58,59)$.

The stereospecificity towards ethanol was shown using ethanol which had been prepared enzymatically from two different deuterated sources. Part of the ethanol was prepared enzymatically from deuterated acetaldehyde, and the other part was prepared from the deuterated reduced form of the coenzyme. When the deuterated ethanol produced from the acetaldehyde was used as the substrate in the enzyme reaction, all the deuterium was found in the acetaldehyde and none in the DPNH. When the ethanol produced from the oxidation of DPND was used as the substrate, all the deuterium was found as DPND and none in the acetaldehyde (58). If there were no specificity towards the ethanol, there should be an equal chance of deuterium occurring in the acetaldehyde or in the coenzyme.

The stereospecificity towards the coenzyme was shown using enzymatically prepared DPND and chemically prepared D'PND. The enzymaticalIy prepared DPND transferred all its deuterium to the acetaldehyde to form monodeutereoethanol, while the chemically prepared DPND transferred $60 \%$ of its deuterium to the acetaldehyde (57). Since the enzyme is 
stereospecific with respect to the coenzyme, it can use only one form of the coenzyme. It has been shown through the use of deuterium that there are two forms of the coenzyme. In one form, the deuterium is above the plane of the pyridine ring. In the other, it is below the plane of the ring. The first form is referred to as form $A$ and the second form is form B. YADH is specific for form A. This explains the difference between the transfer of deuterium by the enzymatically prepared DPND and the chemically prepared DPND. The enzymatic preparation yields only the A form, while the chemically prepared DPND is a mixture of the two forms. With form $B$, YADH transfers the hydrogen rather than the deuterium.

As already mentioned, the solvent does not enter into the oxidation reduction reaction. The transfer of hydrogen is direct from the substrate to the coenzyme, but this does not exclude the possibility that an amino acid group of the enzyme may help in this transfer. Schellenberg has studied this possibility using both tritium labeled coenzyme and substrate $(60,61)$. He found that the coenzyme had to be present in order for the labeling of the enzyme by the substrate to take place, but the substrate did not have to be present for labeling by the coenzyme to take place.

He interrupted the reaction at equilibrium with several different denaturing agents (heat, $\mathrm{HClO}_{4}$ ? $\mathrm{NaOH}$ ) to show that the labeling was not a function of denaturation. Through further studies, Schellenberg was able to show that this labeling took place on the $\beta$-carbon of the tryptophan residue (61). Both Schellenberg and Palm (62) showed labeling to take place non-enzymatically, but this labeling did not take place on 
the tryptophan residue. More evidence is necessary before it can be conclusively stated that the tryptophan residue takes part as an intermediate in the hydrogen transfer from the oubstrate to the coenzyme. There still remains at least one question about hydrogen transfer. This is the question of what is actually transferred. It may be a hydrogen ion and two electrons, a hydride ion, or a hydrogen atom and one electron. Vennesland and coworkers are still working on this question, but so far they have not been able to answer it.

Much of what is known about enzymes has come through inhibition studies. Some of these studies have been used in the preceding pages to describe certain aspects of the enzyme. The inhibition studies that have thus far been carried out with YADH will be organized in tabular form including a short descriptive comment about the inhibition that was observed. 
TABLE VII

INHIBITORS OF YADH

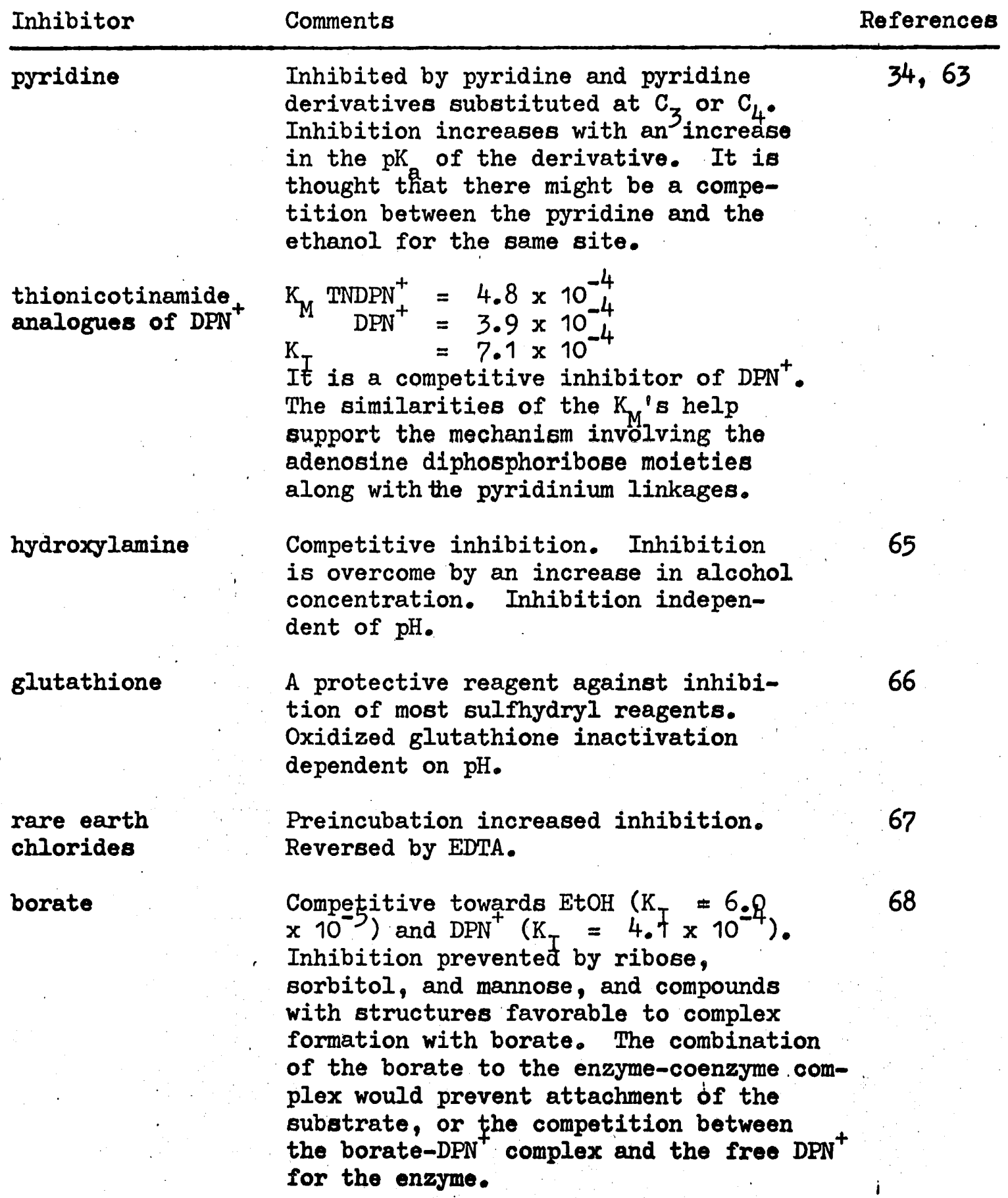


TABLE VII (cont'd)

Inhibitor

Comments

References

$\alpha$-tocopherol, propyl gallate,

Inhibited at low concentration.

69,70 nordihydroguaiaCaused an acceleration of the inactivation by the impurities of the retic acid distilled water. DPN ${ }^{+}$protected the enzyme. Inhibition by propylgallate retarded or eliminated by EDTA.

n-alkylammonium chlorides See Text and Table V.

37,38

Ntalkylnicotin39,40 amide chlorides

42

adenosine

Reversed by increasing the congentra-

36,40

tion of $\mathrm{DPN}^{+} ; \mathrm{K}_{\mathrm{I}}=5.6 \times 10^{-4}$.

adenine diphos-

Competitive with respect to $\mathrm{DPN}^{+}$; phate (ADP) $K_{T}=8.45 \times 10^{-3}$. Competes with 1,10phenanthroline (OP). See Table VI.

adenine diphos-

Competitive with respect to $\mathrm{DPN}^{+}$; phoribose (ADPR) $\mathrm{K}_{\mathrm{I}}=2.65 \times 10^{-3}$. Competes with OP. adenylic acid (AMP) Reversible inhibition. $K_{I}=4.8 \times 10^{-4}$. 41,42 Roussin's salt $\left[\mathrm{Fe}_{4} \mathrm{~S}_{3}\left(\mathrm{NO}_{2}\right)\right] \mathrm{K}$ Competitive with respect to $\mathrm{DPN}^{+}$. Reversible. $\mathrm{K}_{\mathrm{I}}=10^{-5}$ to $10^{-7}$. Reacts with onfy one chemical group, $\mathrm{NH}_{3}{ }^{+}$and the $\mathrm{NH}$ group of the imidazole ring.

phenobarbital

Competitive with respect to $\mathrm{DPN}^{+}$; 4. $\left.\mathrm{K}_{\mathrm{T}}=2.6 \mathrm{Z} \times 10^{-\mathrm{C}}\right)$.

dyes

Fuschin and malachite green competitive with respect to $\mathrm{DPN}^{+}$and $\mathrm{DPNH}$. Crystal violet is non-competitive.

bromopyruvate

Irreversible. Inhibition decreases with increasing $\mathrm{pH}$.

41,42

$36,44,71$

72,73

Irreversible. Coenzyme protects against inhibition. Inhibition increases with increasing $\mathrm{pH}$. 
TABIE VII (cont'd)

Inhibitor

iodoacetate

urea

heat

sulfonyl urea

compounds

chelating agents iodosobenzoate

iodoacetamide

p-chloromercuribenzoate
Comments

References

Inactivation without denaturation. $\mathrm{DPN}^{+}$does not protect the enzyme. Rate of inactivation decreases with an increase in $\mathrm{pH}$. Glutathione does not protect the enzyme.

phenylarsineoxide-

The enzyme is protected against inhibition by glutathione, coenzyme, and substrate.

Glutathione does not protect against inhibition.

Instantaneously inactiyates, but denaturing is slow. DPN protects against denaturation but not inactivation. Reversed with glutathione.

Inhibits reversibly in a concentration less than 3M. Non-competitive irreversible inhibition in a concentration greater than 4M. Inhibition is mainly a result of denaturation. $\mathrm{DPN}^{+}$and EtOH protect against it.

Denaturation protected by $\mathrm{DPN}^{+}$.

Competitive with respect to DPNH.

Exhibit both reversible and irreversible inhibition. See Table VI. Competitive with respect to $\mathrm{DPN}^{+}$. Examples: 1,10-phenanthroline, 2,9dimethyl-1, 10-phenanthroline, 1,5phenanthroline, 5,6-benzoquinoline, 7,8 -benzoquinoline, quinidine, $\alpha, \alpha-$ dipyridyl, 8-hydroxyquinoline, diethyldithiocarbamate, dithizone, 2,3-dimercapto-1-propane, thiourea, thioacetamide, semicarbazide, ammonium-phenylnitrohydroxylamine, azide.
19, 77, 78,79 , 80

19,80

78,79

81

$78,79,80$

82

23,40 ,

83,84 
TABLE VII (cont'd)

Inhibitor

Comments

References

Thiamine

compounds

chloroquine

rotenone

canavanine

chloroproma-

zine

potassium

sorbate

salicylate

aromatic and non-aromatic drugs

sulfanilamide disulfides

oulfonamide disulfides

Heary metal.
Thiamine propyldisulfide, thiamine

disulfide, and thiamine inhibit to

different extents." Appears to react

with the sulfhydryl groups of the

enzyme.

Competitive inhibition.

87

Maximum inhibition of $60 \%$. It is of

mixed type with respect to both $\mathrm{DPN}^{+}$

88

and EtOH.

Appears to be an allosteric inhibitor.

89

$K=5.5 \times 10^{-4}$. Maximum inhibition,

90

75\%. Preincubation has no effect.

Instantaneous inhibition that is

reversible. Not reversed by gluta-

thione.

Inhibition is dependent on $\mathrm{pH}$. Not

as strong an inhibitor in alkaline $\mathrm{pH}$.

Degree of inhibition essentially con-

stant after 5 minutes. Irreversible.

Competitive with respect to $\mathrm{DPN}^{+}$and

EtOH.

Competitive with respect to $\mathrm{DPN}^{+}$.

92,93

Inhibition correlated with aromatic

and/or planar properties of the

molecules.

Inhibition is $\mathrm{pH}$ dependent. Noncompetitive inhibition with respect to the coenzyme. Mixed type of inhibition with respect to the substrate. Inhibition connected with the reaction between the disulfide group and the thiol group of the enzyme. . Inhibition depends on time of incubation. 98,99
Maximum around $\mathrm{pH} 10$.

YADH is very sensitive to the heavy 100 95, 96, 97 85,86

94 metal. Inhibition appears to follow the solubility of the metal sulfides. 
METHODS AND EXPERIMENTAI DATA

\section{Materials and Methods}

Yeast alcohol dehydrogenase in $2.4 \mathrm{M}$ ammonium sulfate, A grade (Calbiochem); $\mathrm{DPN}^{+}$, ethanol free (Nutritional Biochemicals Corporation); $\mathrm{K}_{2} \mathrm{HPO}_{4}$, reagent grade (Baker \& Adamson); $\mathrm{KH}_{2} \mathrm{PO}_{4}$, reagent grade (Baker \& Adamson); $\mathrm{Na}_{4} \mathrm{P}_{2} \mathrm{O}_{7} \cdot 10 \mathrm{H}_{2} \mathrm{O}$, reagent grade (Baker \& Adamson); NaF, reagent grade (Baker \& Adamson); KF, analytical reagent grade (Baker \& Adamson).

The activity of the yeast alcohol dehydrogenase (YADH) was measured on the Cary Model 14 Spectrophotometer by following the rate of production of DPNH which is observed as an increase in optical density with time at $340 \mathrm{~m} \mu_{0}$. The reaction mixture contained $0.5 \mathrm{ml}$ of $6 \times 10^{-2} \mathrm{M}$ pyrophosphate buffer of $\mathrm{pH} 8.5 ; 0.1 \mathrm{ml}$ of enzyme solution; and varying amounts of $1.5 \times 10^{-2} \mathrm{M} \mathrm{DPN}^{+}$and $3 \mathrm{M}$ ethanol (EtOH). The final volume was adjusted to $3 \mathrm{ml}$ by the addition of distilled $\mathrm{H}_{2} \mathrm{O}$ in a $1 \mathrm{~cm}$ cuvette. The water, buffer, and $\mathrm{DPN}^{+}$were added to the cuvette in this order with the enzyme being added last just before the instument was zeroed. The reaction mixture was stirred and the instmument was zeroed. The reaction was initiated by the addition of ethanol from a syringe. The reaction mixture was stirred and the rate of change in absorbance was recorded by the instrument.

By the definition of Racker (4), one unit. of enzyme is that amount of enzyme necessary to produce a change of 0.001 in absorbance, per minute under standard assay conditions. Standard assay conditions speci- 
fy $0.5 \mathrm{ml}$ of pyrophosphate buffer of $\mathrm{pH} 8.5 ; 0.1 \mathrm{ml}$ of enzyme solution; $0.1 \mathrm{ml}$ of $\mathrm{DPN}^{+}$and $0.1 \mathrm{ml}$ of ethanol. The volume is adjusted to $3 \mathrm{ml}$ by the addition of $2.2 \mathrm{ml}$ of distilled $\mathrm{H}_{2} \mathrm{O}$. Once the activity of the enzyme solution was determined, it was diluted with $10^{-2} \mathrm{M}$ potassium phosphate buffer of $\mathrm{pH} 7.5$, to give an enzyme solution containing approximately 400 to 600 units per $0.1 \mathrm{ml}$ for use in inhibition studies. A standard assay graph is shown in Figure 2.

The activity of the solution for the standard assay graph is calculated from the change in absorbance for a 15 second interval during the initial part of the reaction while the reaction is linear with time. For this solution, the change was 0.100 in 15 seconds. This is a change: of 0.400 absorbance units per minute. According to the definition of Racker, this solution contained 400 units of enzyme. Since $0.1 \mathrm{ml}$ of the enzyme solution was added, the activity of this solution was 4,000 units/ml. This is the lower limit of activity for inhibition studies. To determine the protein content of an enzyme solution, Warburg and Christian (101) worked out a method based on absorption which does not require the use of a standard curve. This method gives the protein concentration of enzyme solutions fairly accurately even though enzymes vary in their amino acid composition. Warburg and Christian developed a series of factors which relate the absorbance of an enzyme solution at $280 \mathrm{~m} \mu$ to the protein concentration. These factors correlate the ratio of the absorbance of tyrosine and tryptophan at $280 \mathrm{~m} \mu$ and $260 \mathrm{~m} \mu$ to the total protein concentration. They also account for absorbance due to nucleic acids at these wavelengths, since nucleic acids are often present in crude enzyme preparations. These correction factors, when 


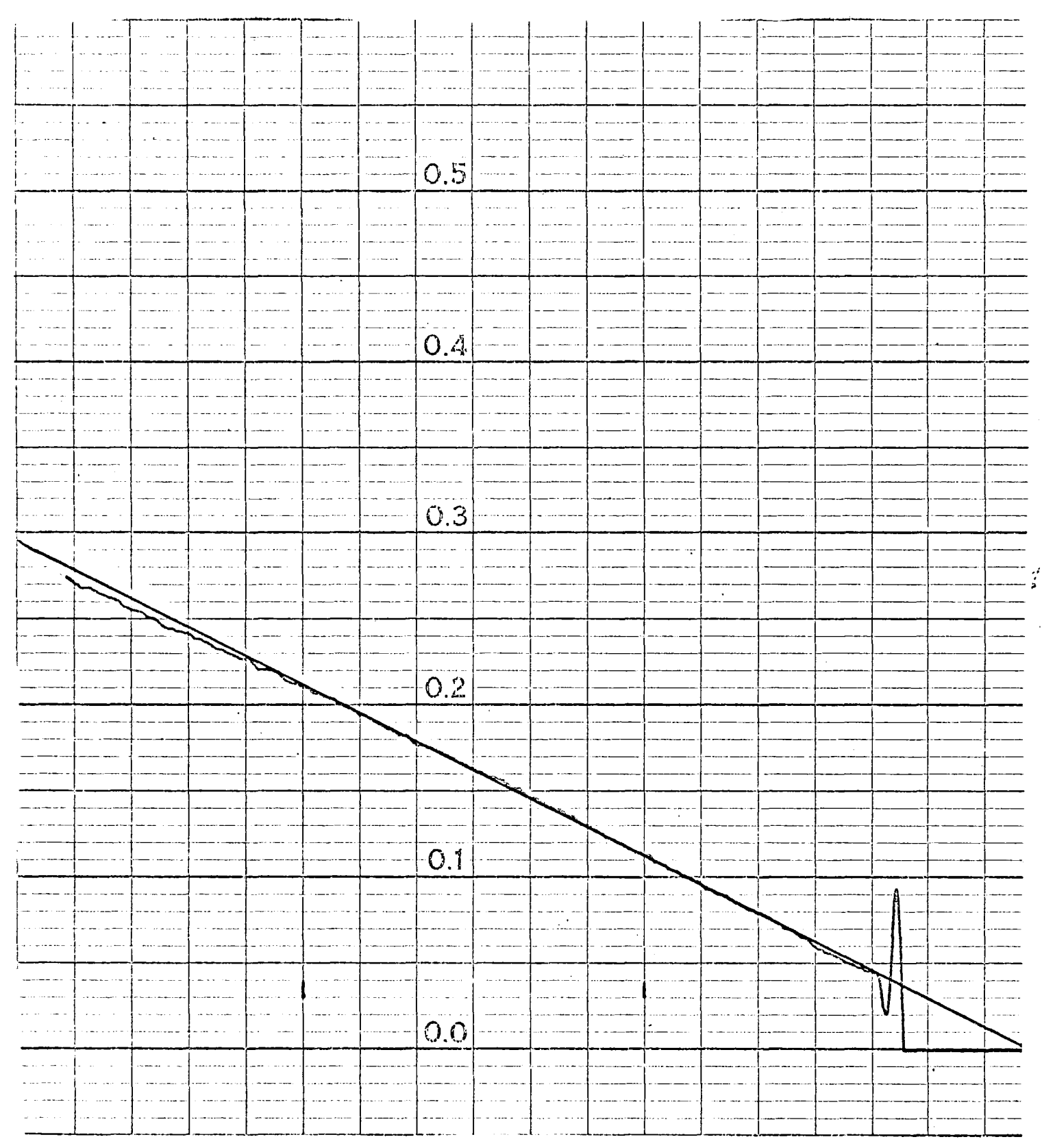

Figure 2. Standard Assay Graph Absorbance vs time. Chart speed 8 in/min. 
multiplied by the absorbance at $280 \mathrm{~m} \mu$, give the protein content of the enzyme solution in $\mathrm{mg} / \mathrm{ml}$.

Figure 3 shows the absorption spectrum between 260 and $280 \mathrm{~m} \mu$ for the enzyme solution used for the standard assay graph. The absorbance at $260 \mathrm{~m} \mu$ is 0.415 and at $280 \mathrm{~m} \mu$ is 0.401 . The $A_{28 \sigma^{\prime}} \mathrm{A}_{260}$ ratio is 0.966 . From the table given by Chaykin (102), the factor is 0.765 . When this is multiplied by the absorbance at $280 \mathrm{~m} \mu$, one finds that this enzyme solution contained $0.307 \mathrm{mg}$ of protein per milliliter.

One can now calculate the specific activity of this enzyme solution. This is an indication of the purity of an enzyme solution, and is particularly valuable during recrystallization. To determine this value, one divides the activity by the protein content. For this enzyme solution, it was 13,029 units/mg.

Plots of initial velocity versus substrate concentration and of initial velocity versus coenzyme concentration are presented in Figures 4 through 7. These plots show that the enzyme reaction reaches a point of saturation above which further addition of substrate or coenzyme does not increase the rate of reaction. In an enzyme reaction, such as that of $\mathrm{YADH}$, where the reaction is dependent on both a coenzyme and a substrate, it is very important to keep the concentration of the one that is being held constant at a point of saturation; so that the change in the reaction rate is due only to the substance being varied.

For the inhibition studies with $\mathrm{NaF}, \mathrm{KF}, \mathrm{NaCl}$, and $\mathrm{KCl}$, the enzyme solutions varied from approximately 400 to 700 units. The salt solutions varied from 0.001 to $0.12 \mathrm{M}$ in concentration. Both potassium and sodium salts were used to show any possible effect of the cation. The salt 


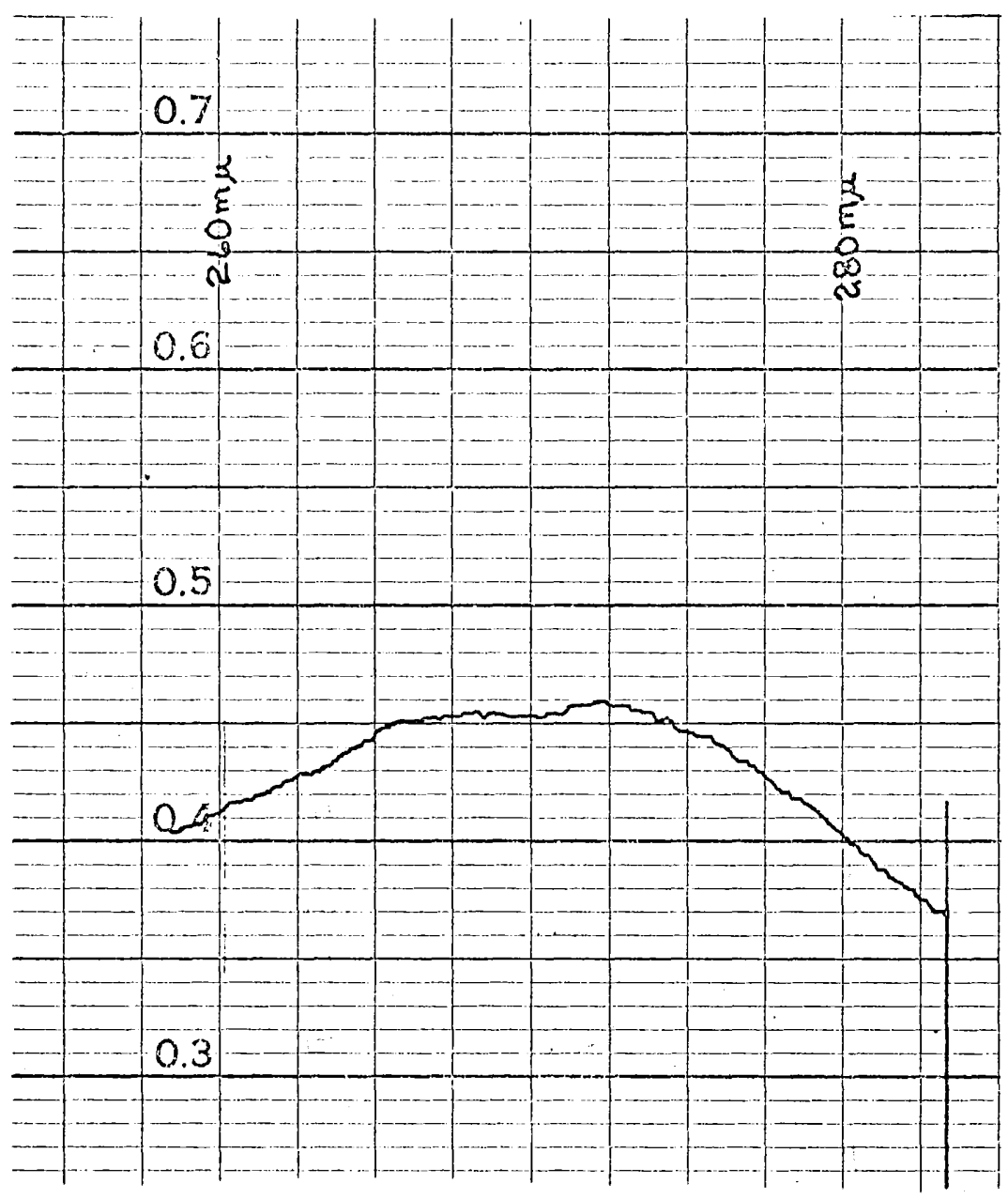

Figure 3. Absorption Spectrum of Yeast Alcohol Dehydrogenase. 


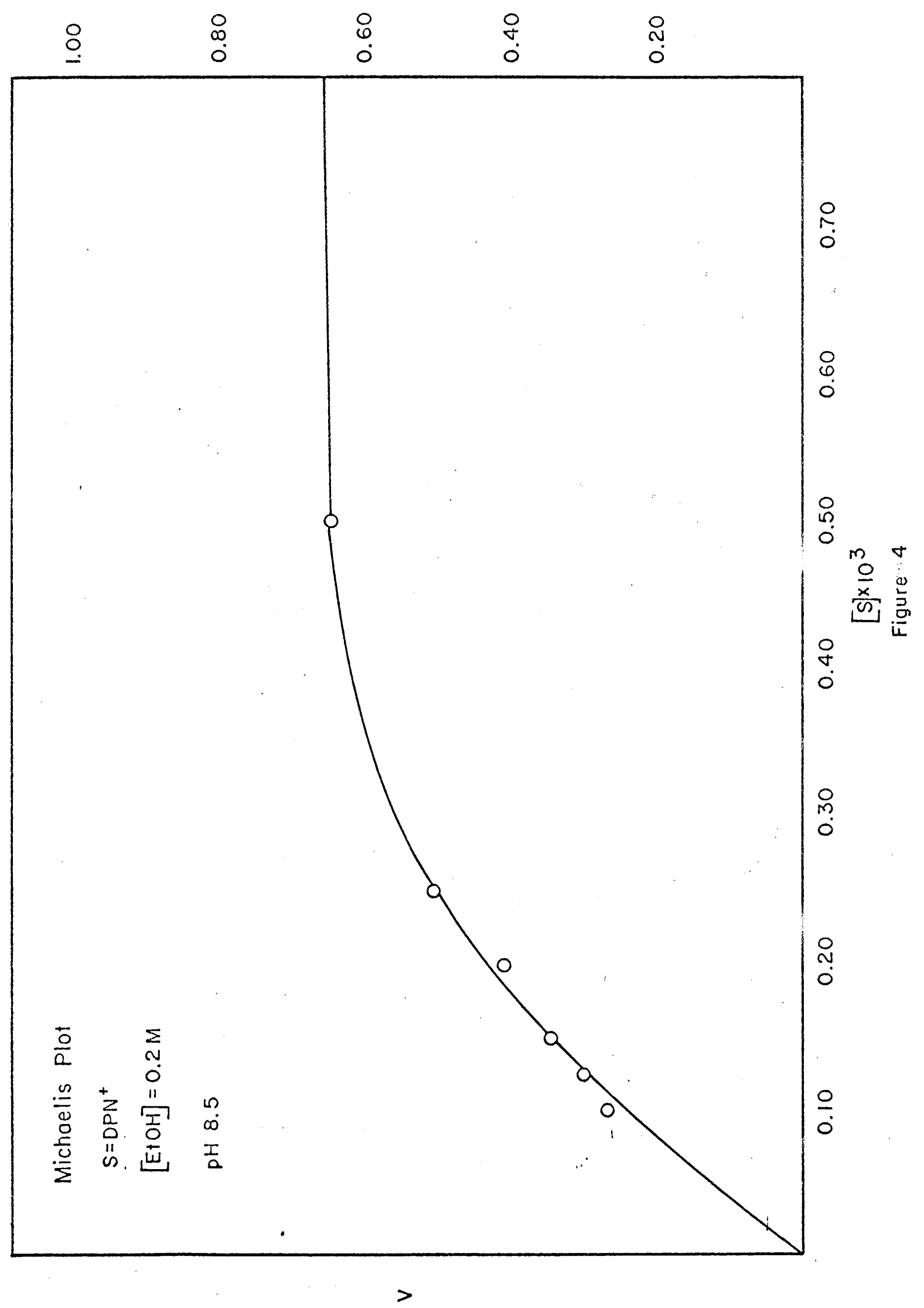




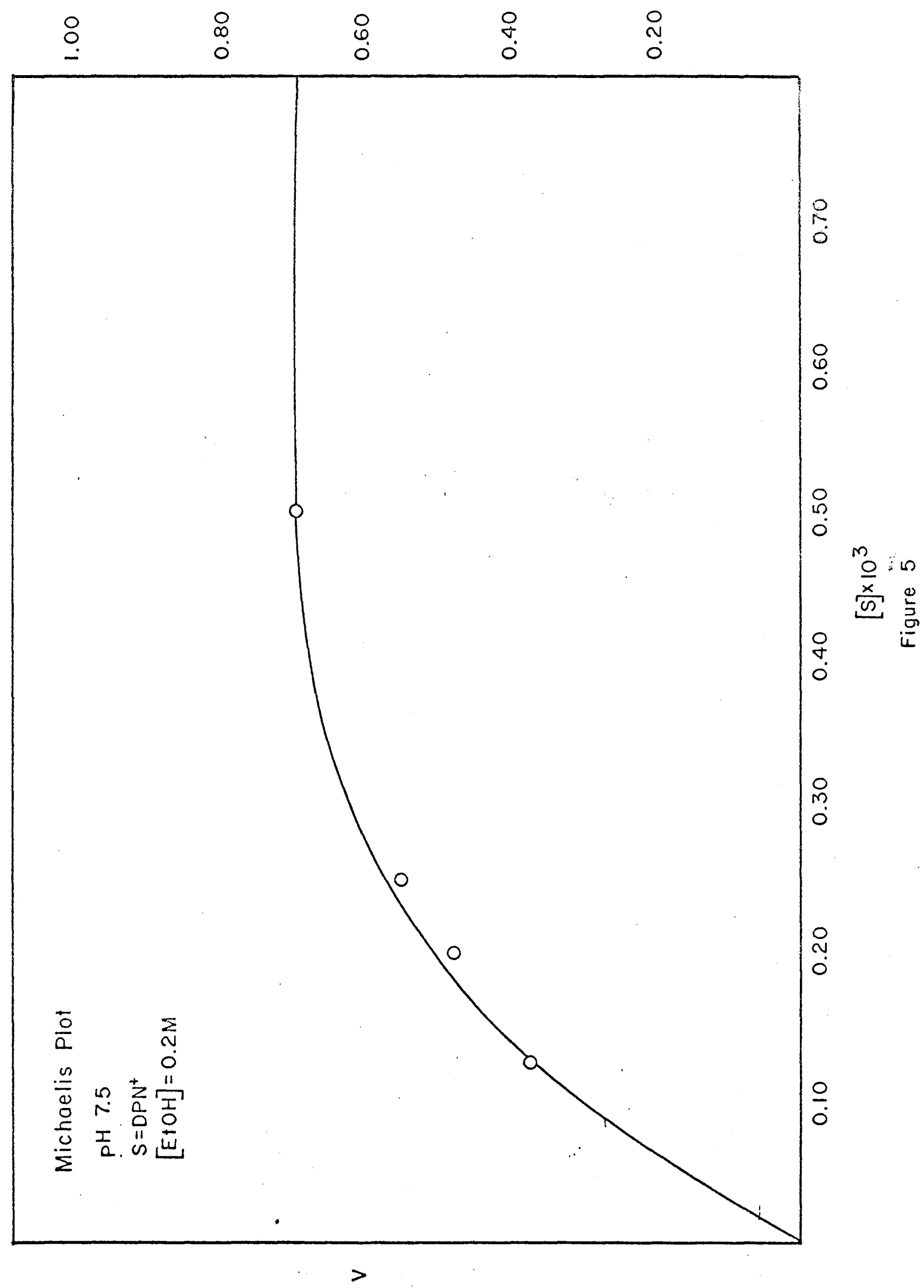



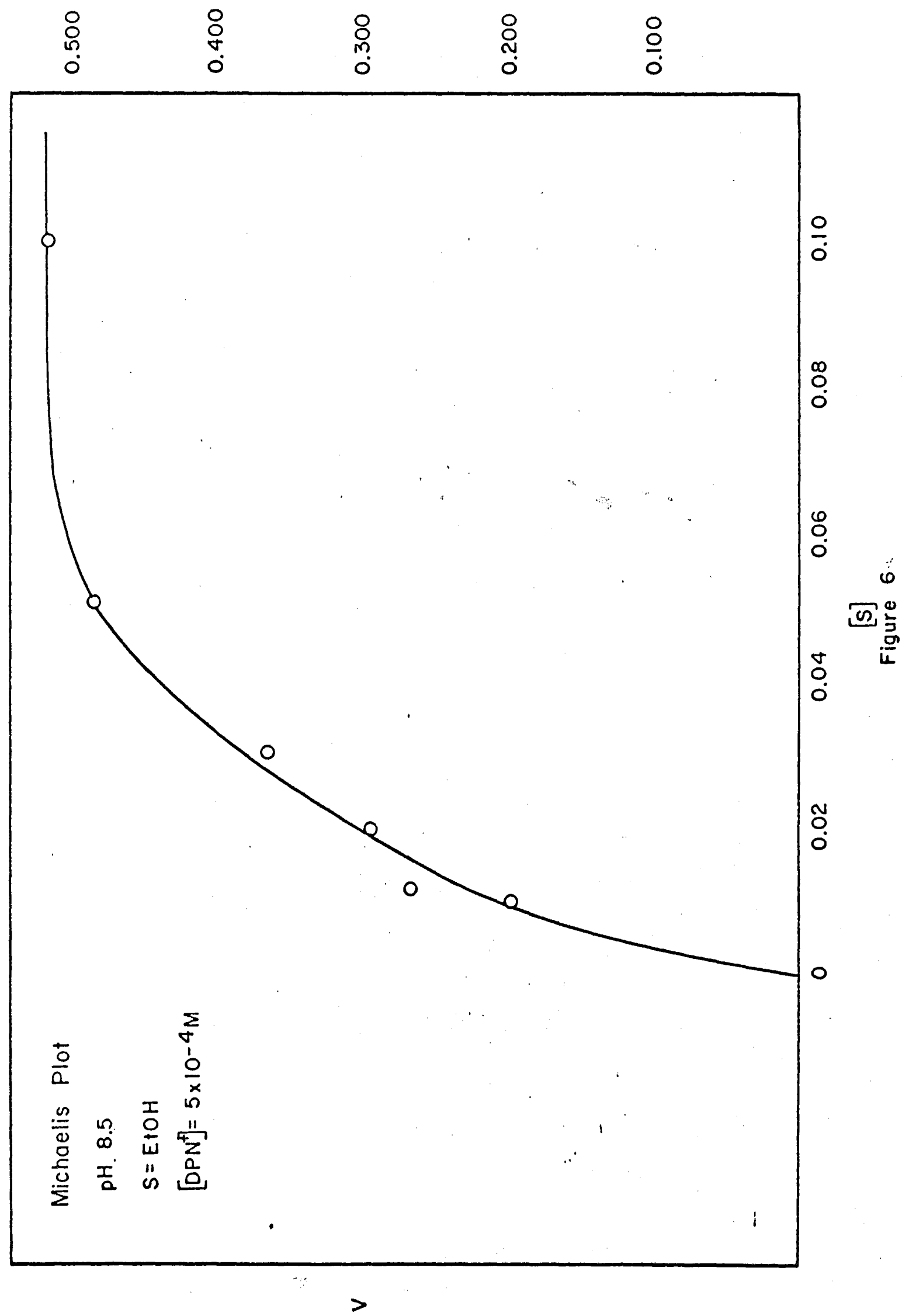


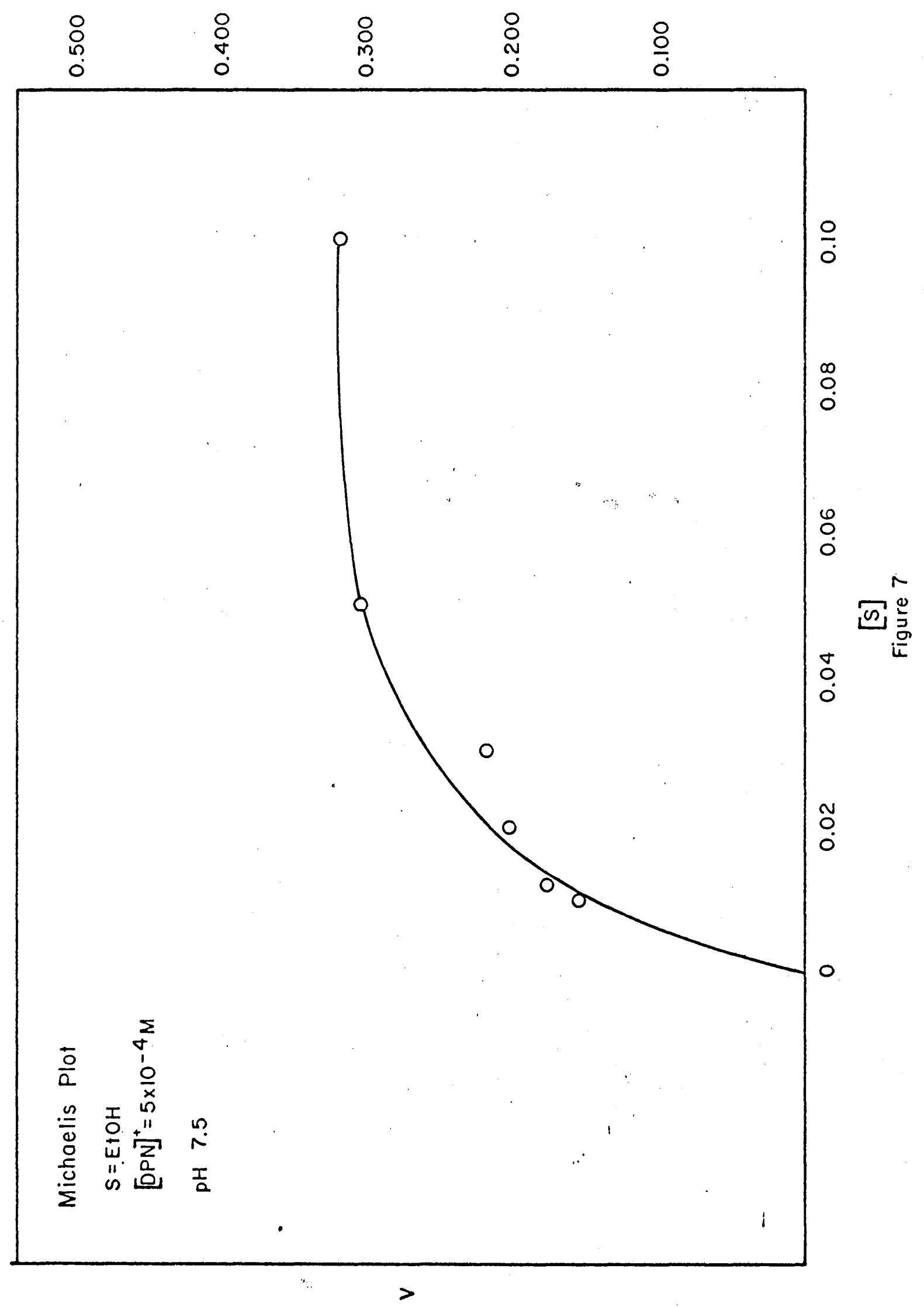


solution was added to the reaction mixture in the cuvette immediately before the reaction was started to prevent any possible effect of time of contact in inhibiting or activating the reaction.

Some of the inhibition studies were done holding the $\mathrm{DPN}^{+}$concentration constant at $5 \times 10^{-4} \mathrm{M}$ while the ethanol concentration was varied from 0.01 to $0.1 \mathrm{M}$. During the rest of the studies, the ethanol concentration was held constant at $0.2 \mathrm{M}$ while the $\mathrm{DPN}^{+}$concentration was varied from $5 \times 10^{-5}$ to $5 \times 10^{-4} \mathrm{M}$.

The inhibition studies were conducted at two different pH levels. Since $\mathrm{pH} 8.5$ is the optimum $\mathrm{pH}$ of the enzyme (9), it was chosen as one $\mathrm{pH}$, and $\mathrm{pH} 7.5$ was chosen as the other one because it is closer to physiological pH. For the studies at pH 7.5, the pyrophosphate buffer of $\mathrm{pH} 8.5$ was replaced with $0.5 \mathrm{ml}$ of $6 \times 10^{-2} \mathrm{M}$ pyrophosphate buffer of $\mathrm{pH} 7.5$.

The reactions were mun at $27^{\circ} \mathrm{C} \pm 0.5^{\circ} \mathrm{C}$. Since there is no constant temperature bath on the instrument, the temperature of the reaction mixture was recorded at the beginning and at the end of the reaction, and found to vary not more than $0.5^{\circ} \mathrm{C}$. A thermometer was kept inside the cell compartment to check variation in cell compartment temperature. This was found not to vary mare than $1^{\circ} \mathrm{C}$.

\section{Treatment of Data}

The initial velocities of the reactions were determined from the instrument recordings. These data were then graphed in two different ways. One method made, use of the Michaelis-Menten equation (103):

$$
v_{0}=\frac{v_{\operatorname{Max}}(s)}{(s)+K_{M}}
$$


Lineweaver and Burk (103) rearranged this equation in such a manner that the $v_{0}$ and $(s)$ were linear functions of each other. Using the following equation,

$$
\frac{1}{v_{0}}=\frac{1}{V_{\operatorname{Max}}}+\frac{K_{M}}{V_{M a x}} \cdot \frac{1}{(s)}
$$

they graphed $1 / v_{0}$ vs $1 /(g)$. Graphically, $1 / N_{\text {Max }}$ will be the $y$ intercept and $\mathrm{K}_{\mathrm{M}} / \mathrm{v}_{\mathrm{Max}}$ will be the slope. In this type of graph, $1 / v$ tends to show little variation at high substrate concentrations.

The other method of graphing the data is called a Hanes plot. The Hanes plot tends to place a more even distribution on the points even though it is based on the same original equation (103). Hanes rearranged the equation to read (103):

$$
\frac{(s)}{v_{0}}=\frac{(s)}{V_{\operatorname{Max}}}+\frac{K_{M}}{v_{M a x}}
$$

Hanes graphed $(S) / v_{0}$ vs $(S)$, where the slope equals $1 / v_{\text {Max }}$ and the $y$ intercept equals $\mathrm{K}_{\mathrm{M}} / \mathrm{V}_{\mathrm{Max}}$.

Together these plots were used to determine points which were inconsistent and beyond experimental error. These points were deleted in the final Lineweaver-Burk plots which are shown in Figures 8 through 26. Hanes plots are shown in Figures 9, 20, \& 22. The maximal velocities and Michaelis constants calculated from the two different methods agree reasonably well.

The percent activity was calculated as $\mathrm{V}_{\operatorname{Max}} / \mathrm{V}_{\operatorname{Max}}$, where $\mathrm{V}_{\mathrm{Max}}$ was the maximum velocity observed in the presence of added salts, and $v_{\text {Max }}$ was the maximum velocity observed in the absence of added salts. This ratio was plotted as a function of the square root of the ionic strength. 


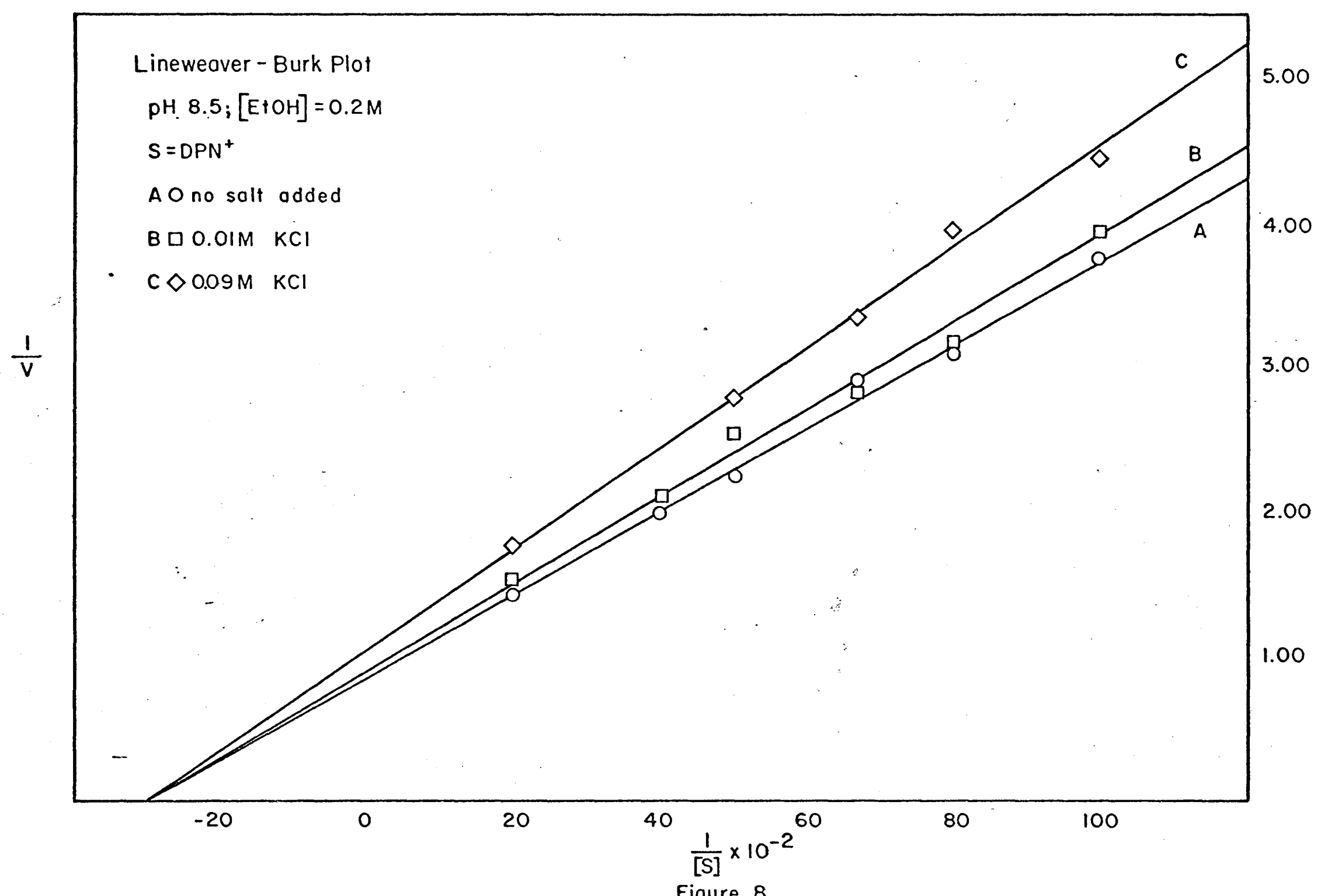




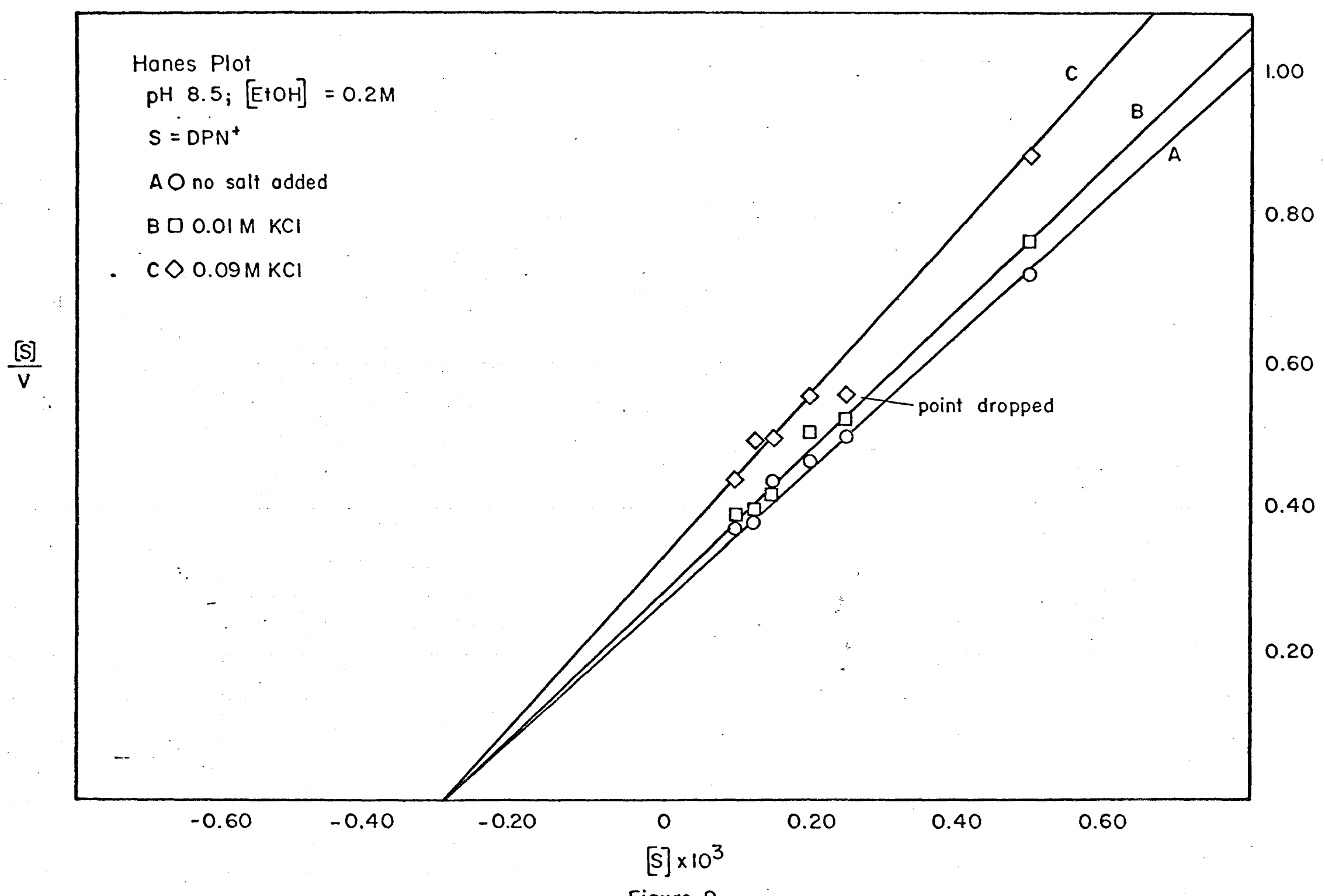

Figure 9 


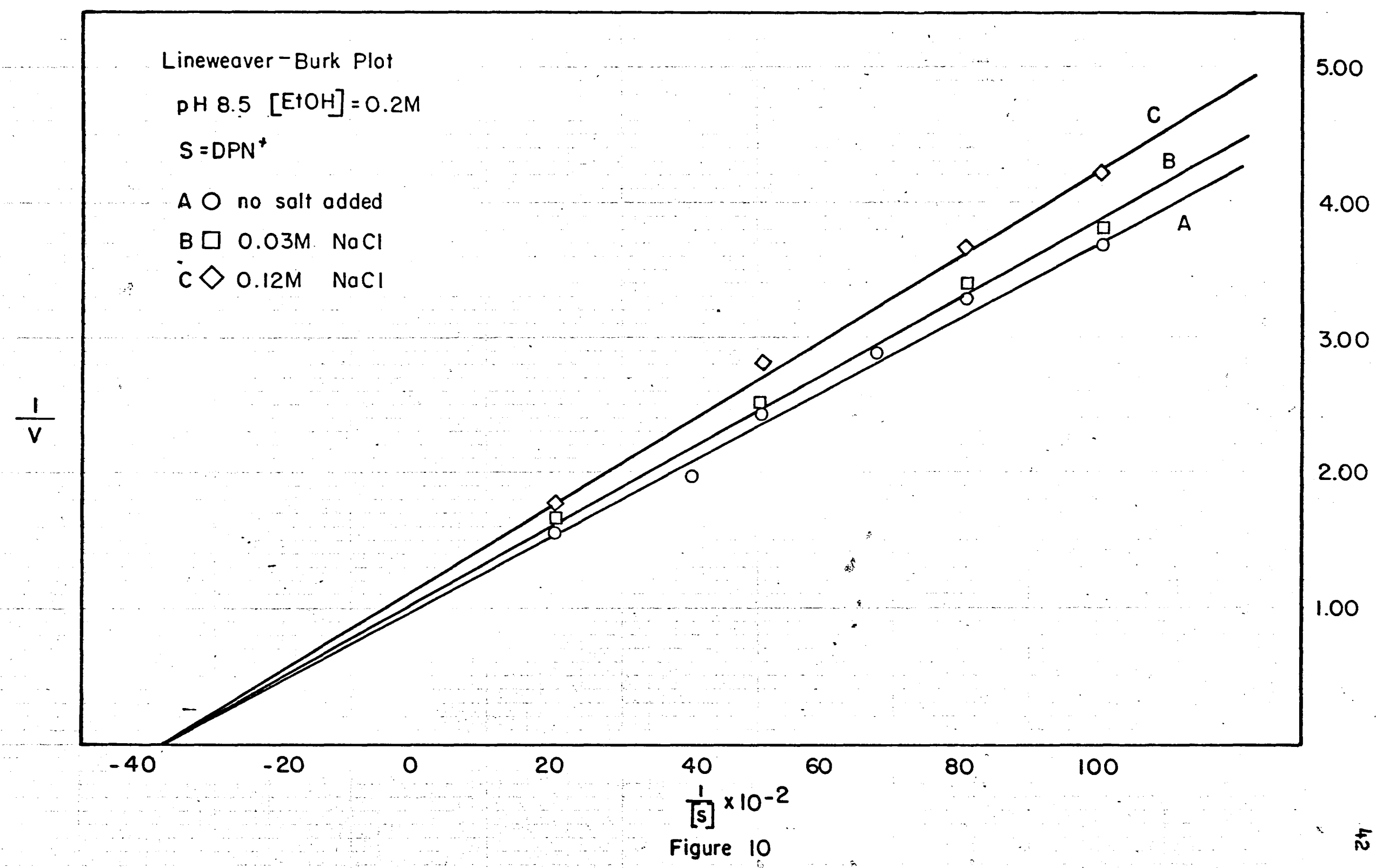




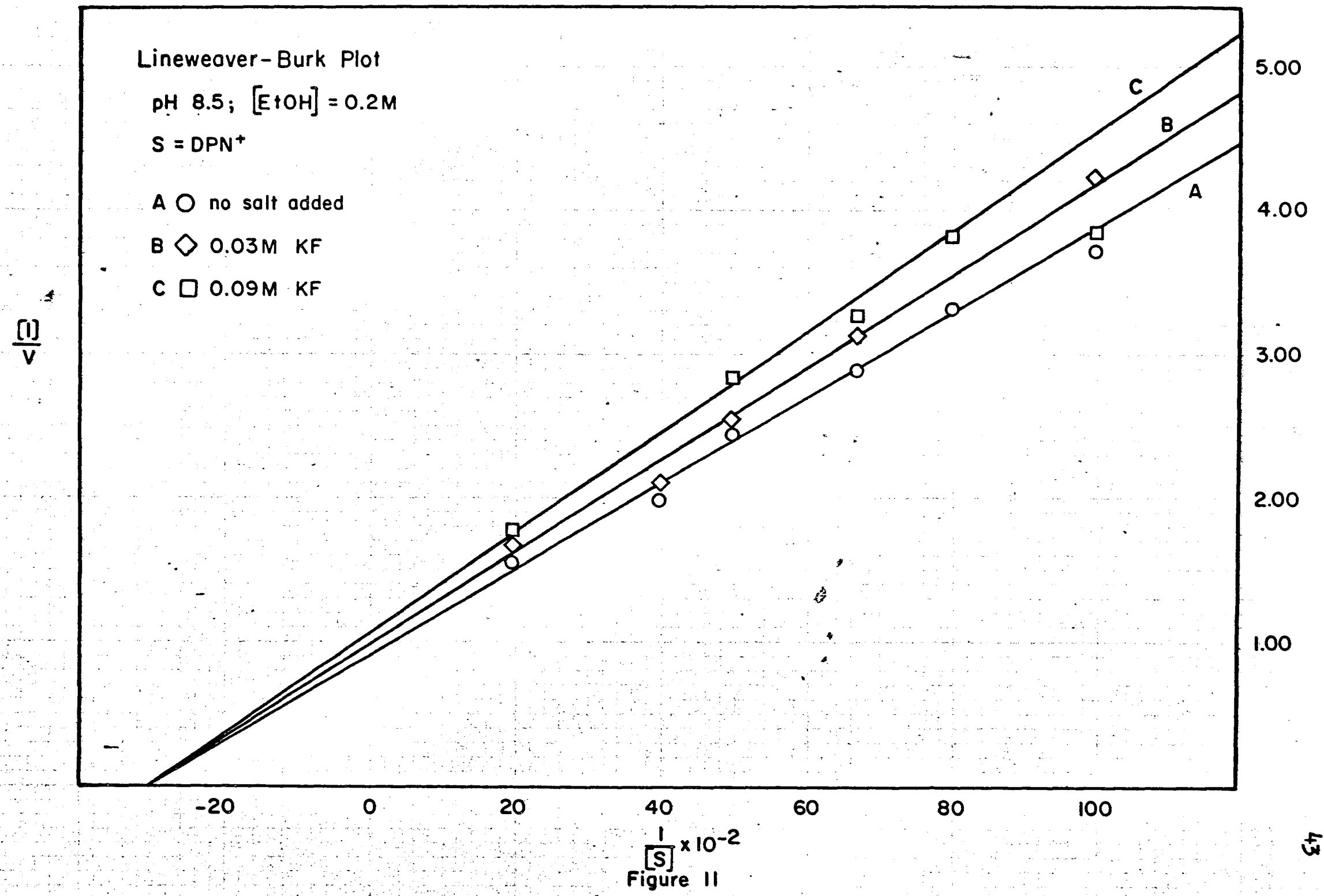




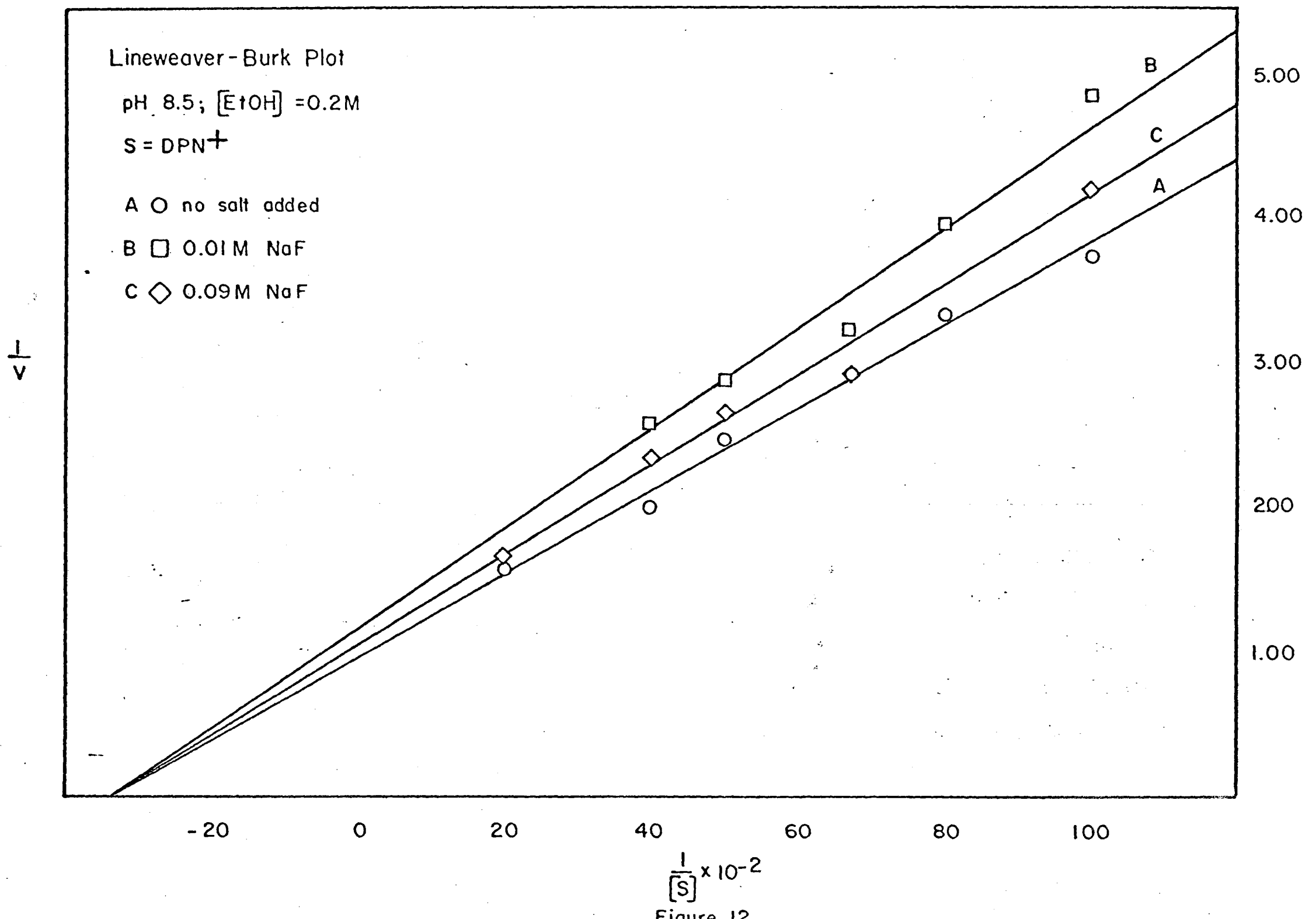




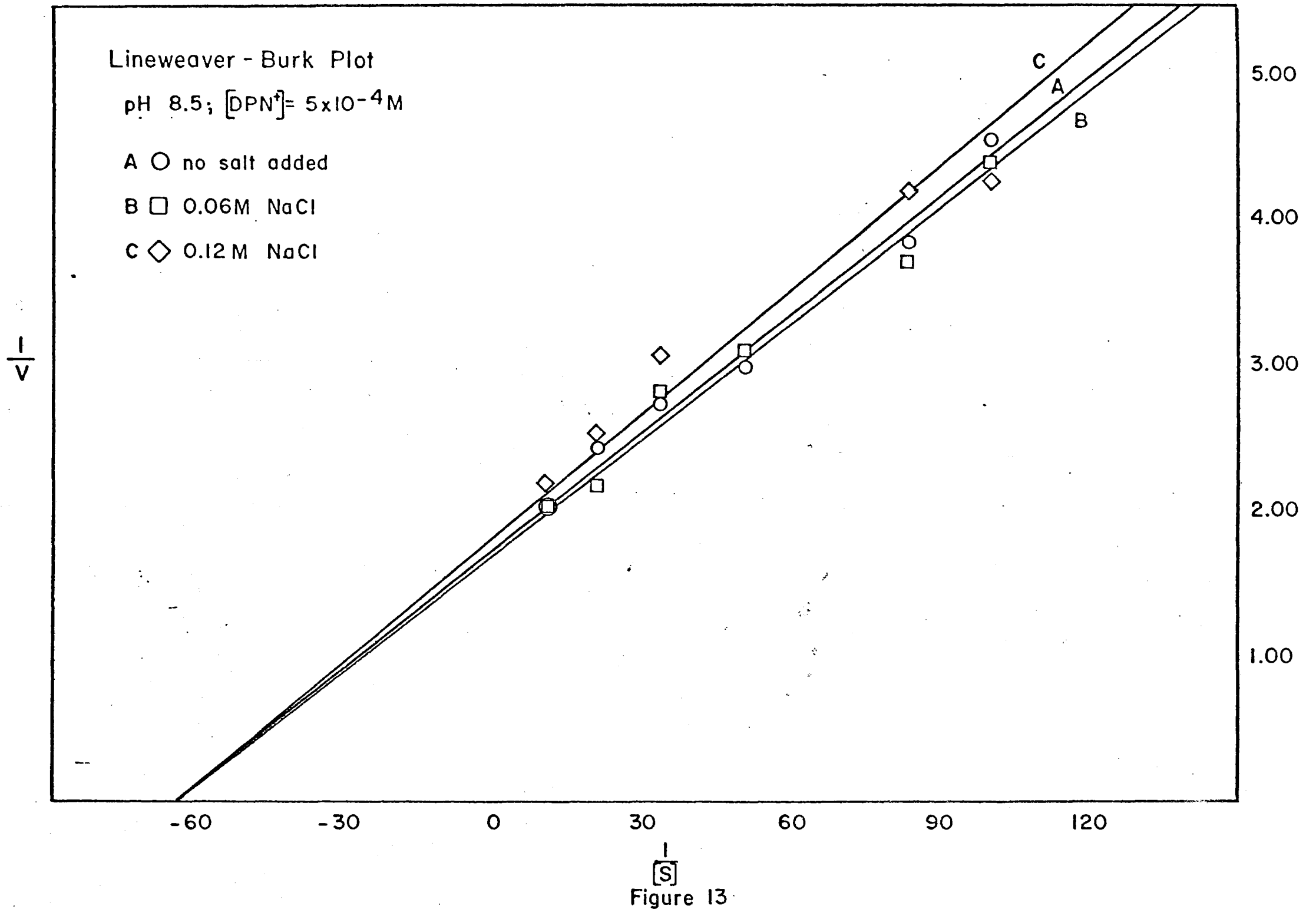




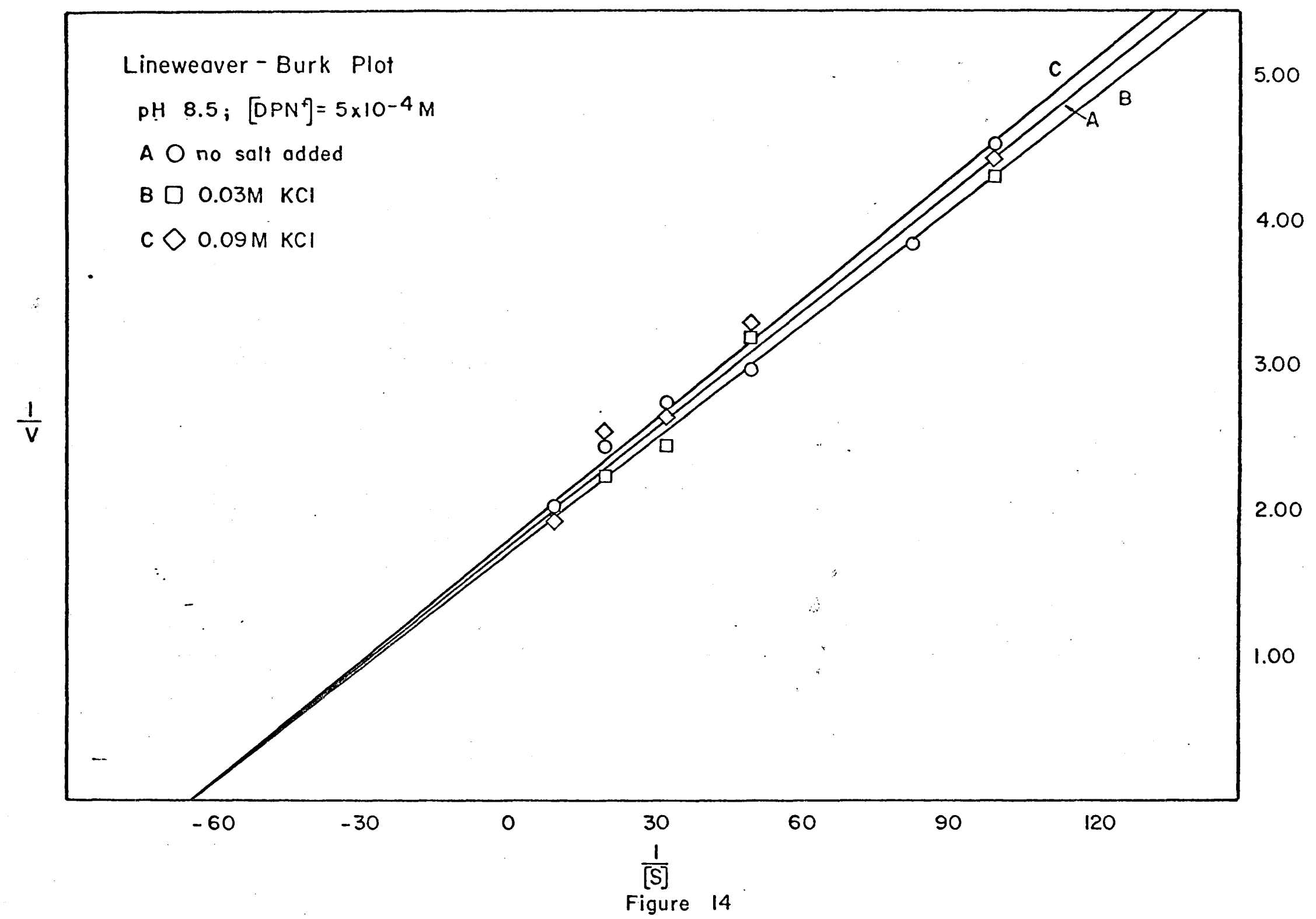




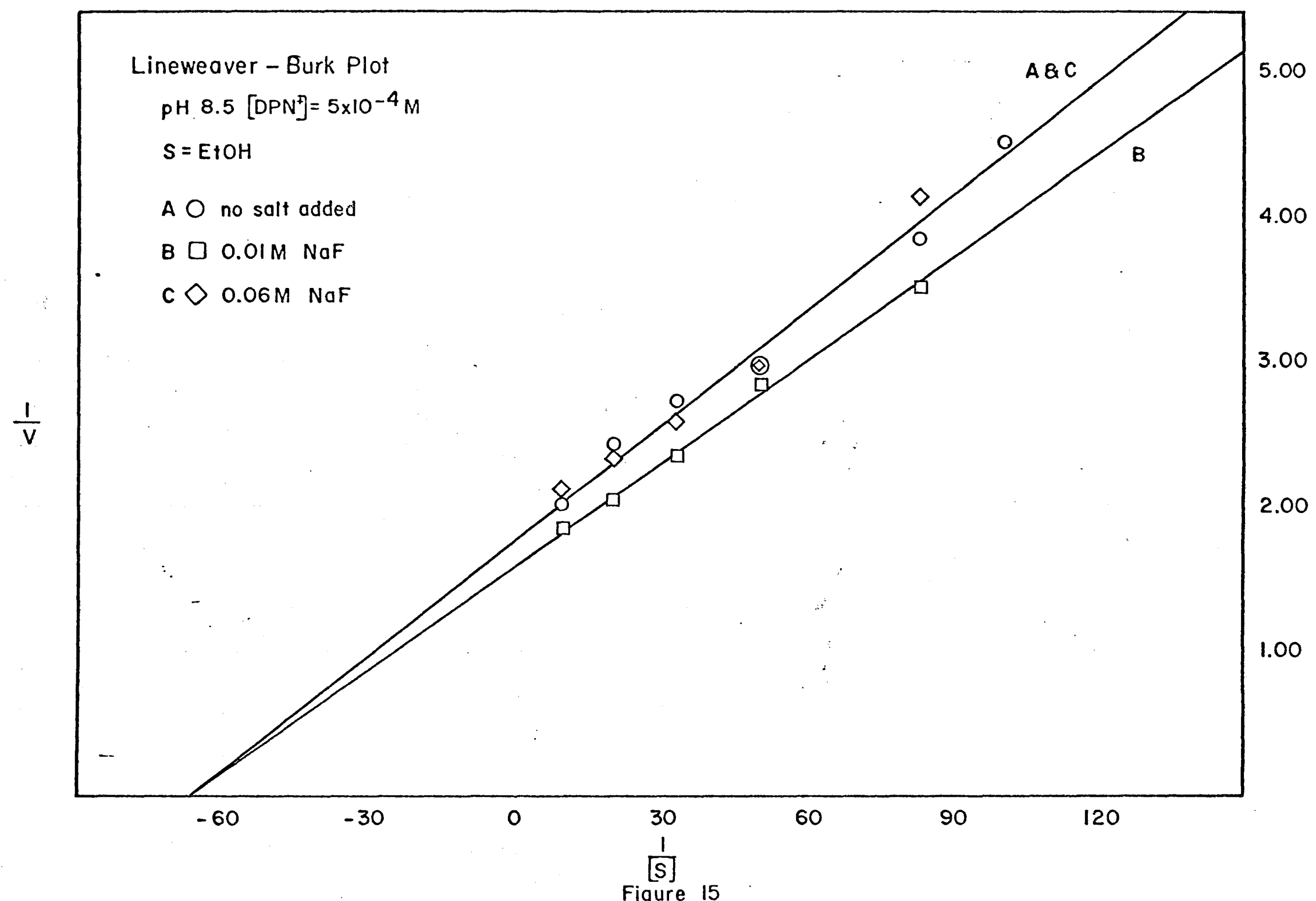




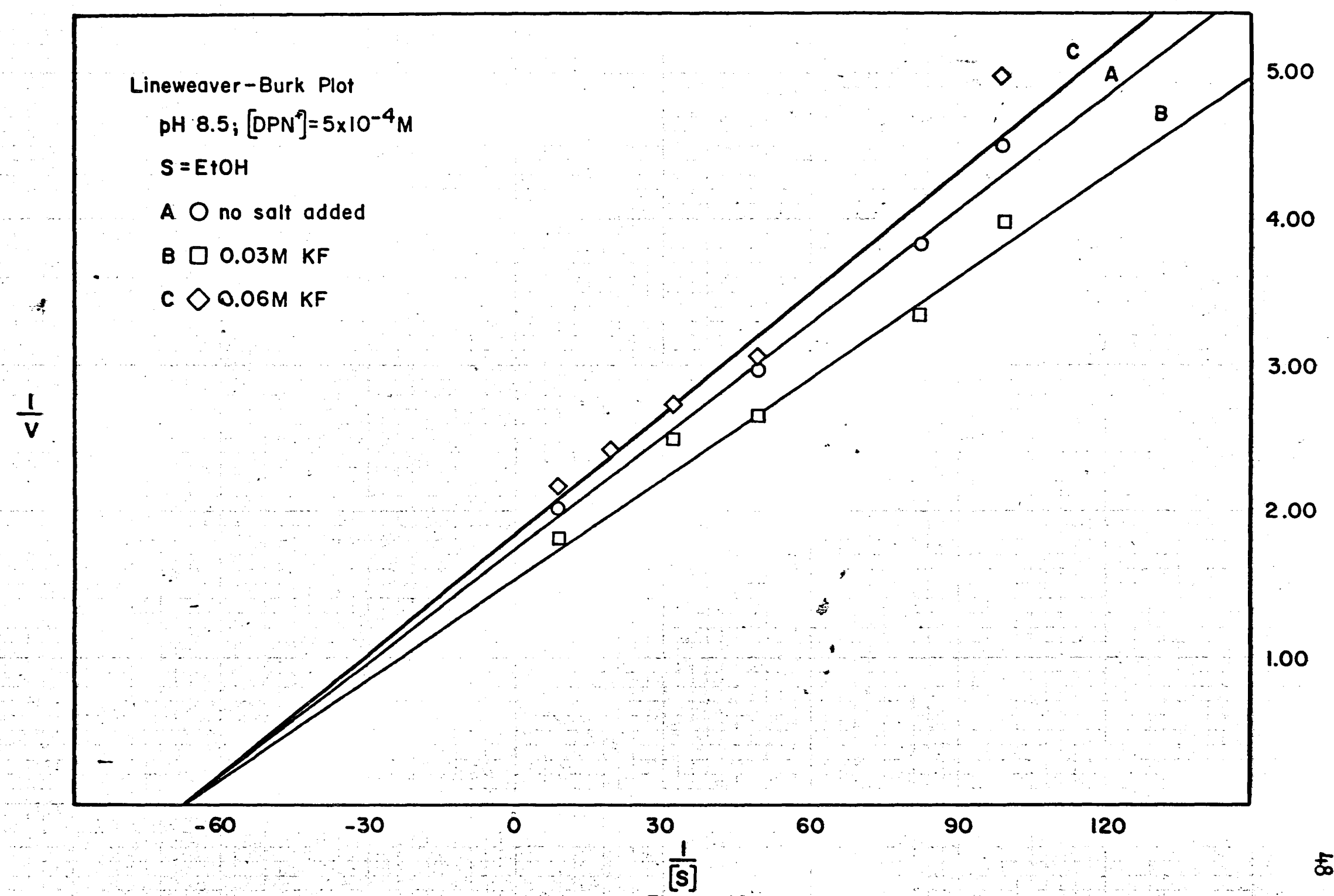

Figure 16 


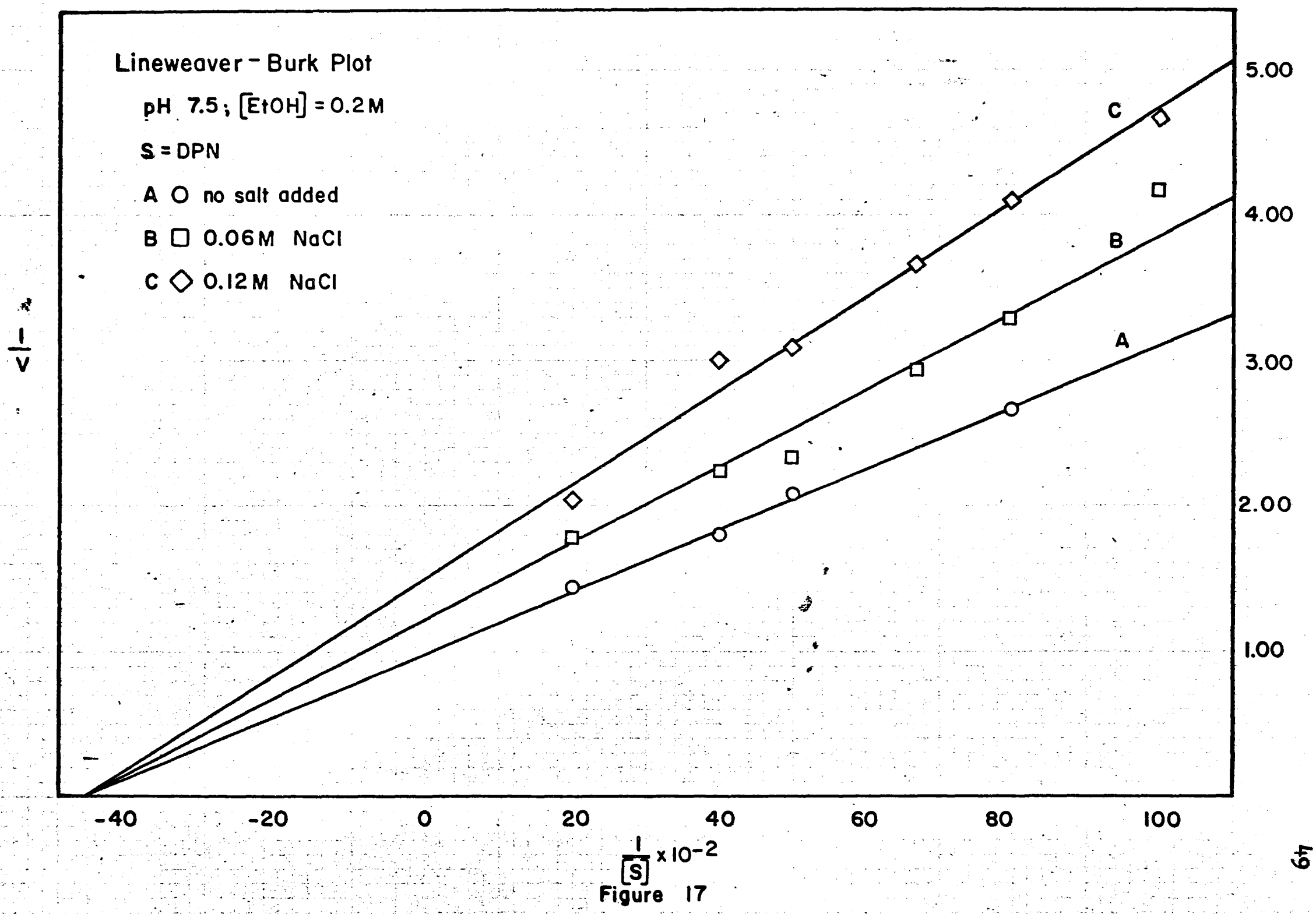




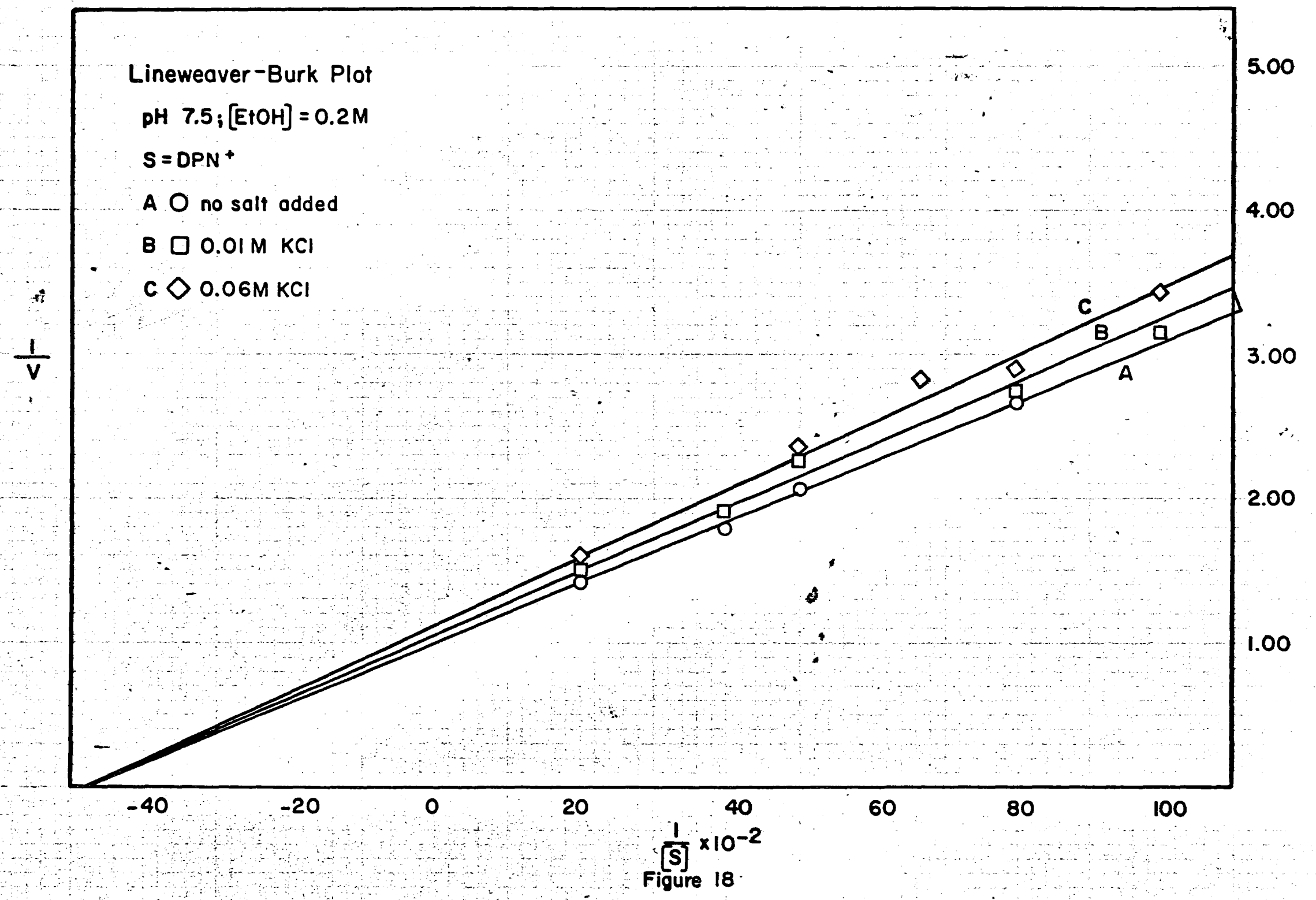




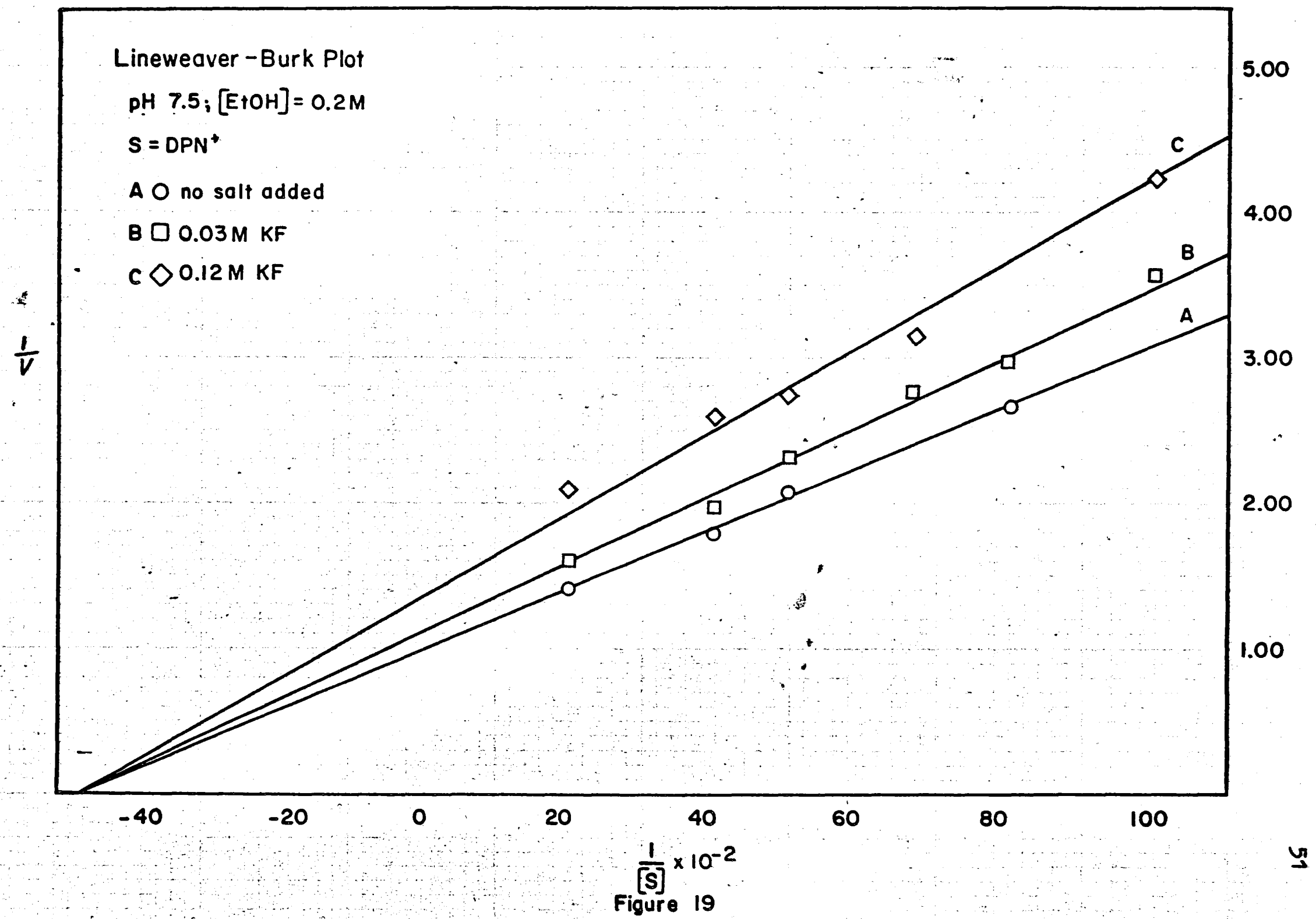




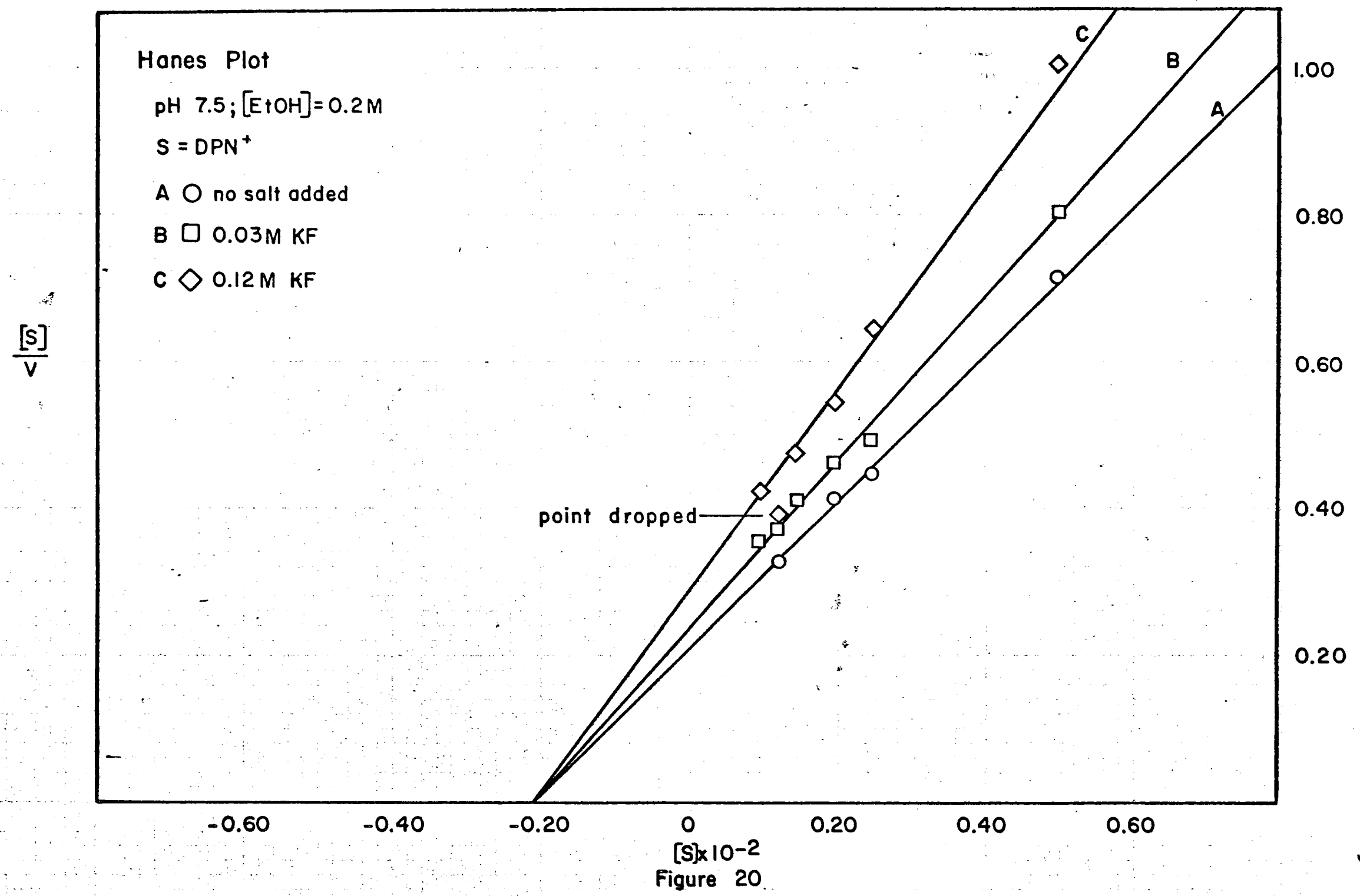




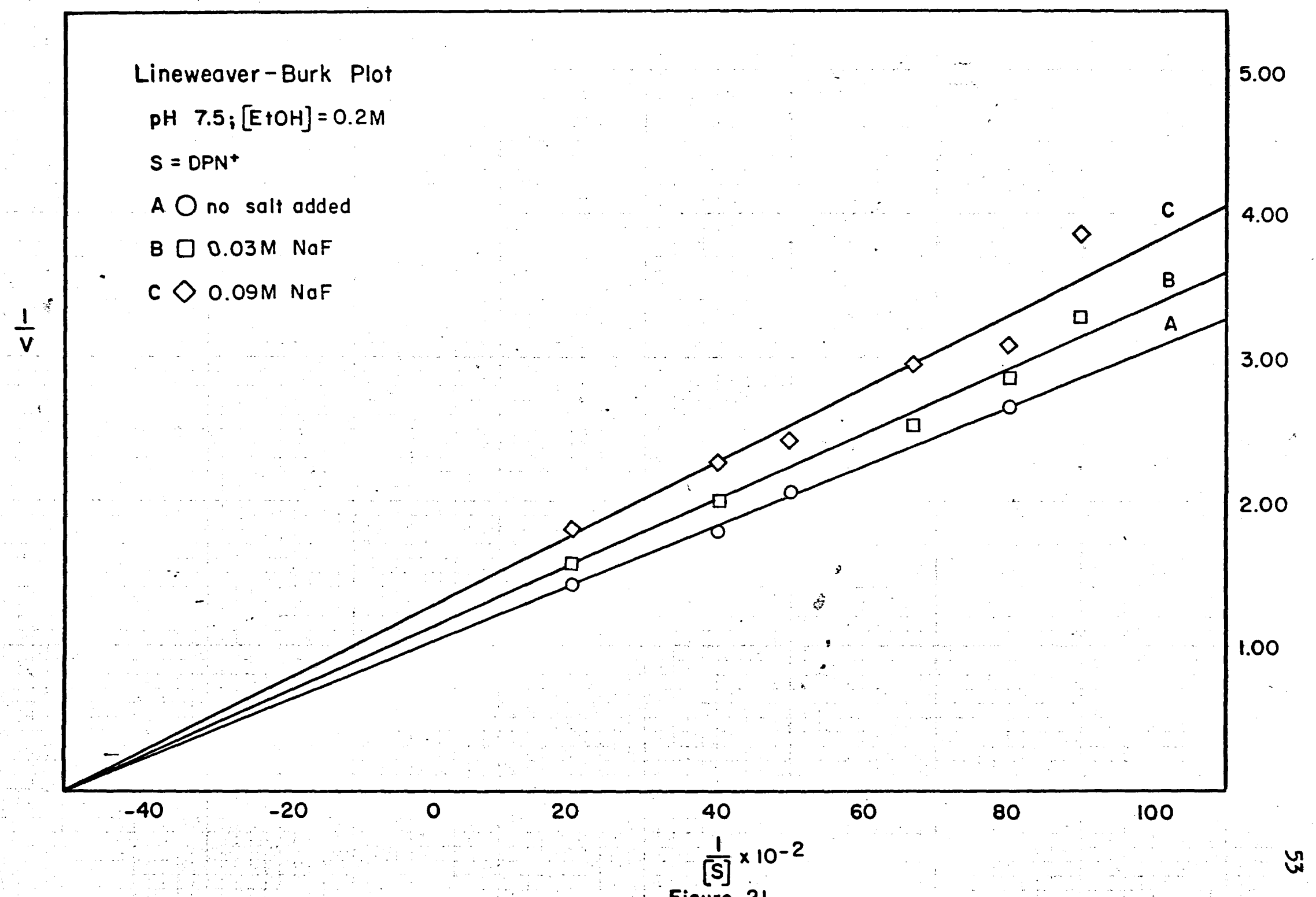

Figure 21 


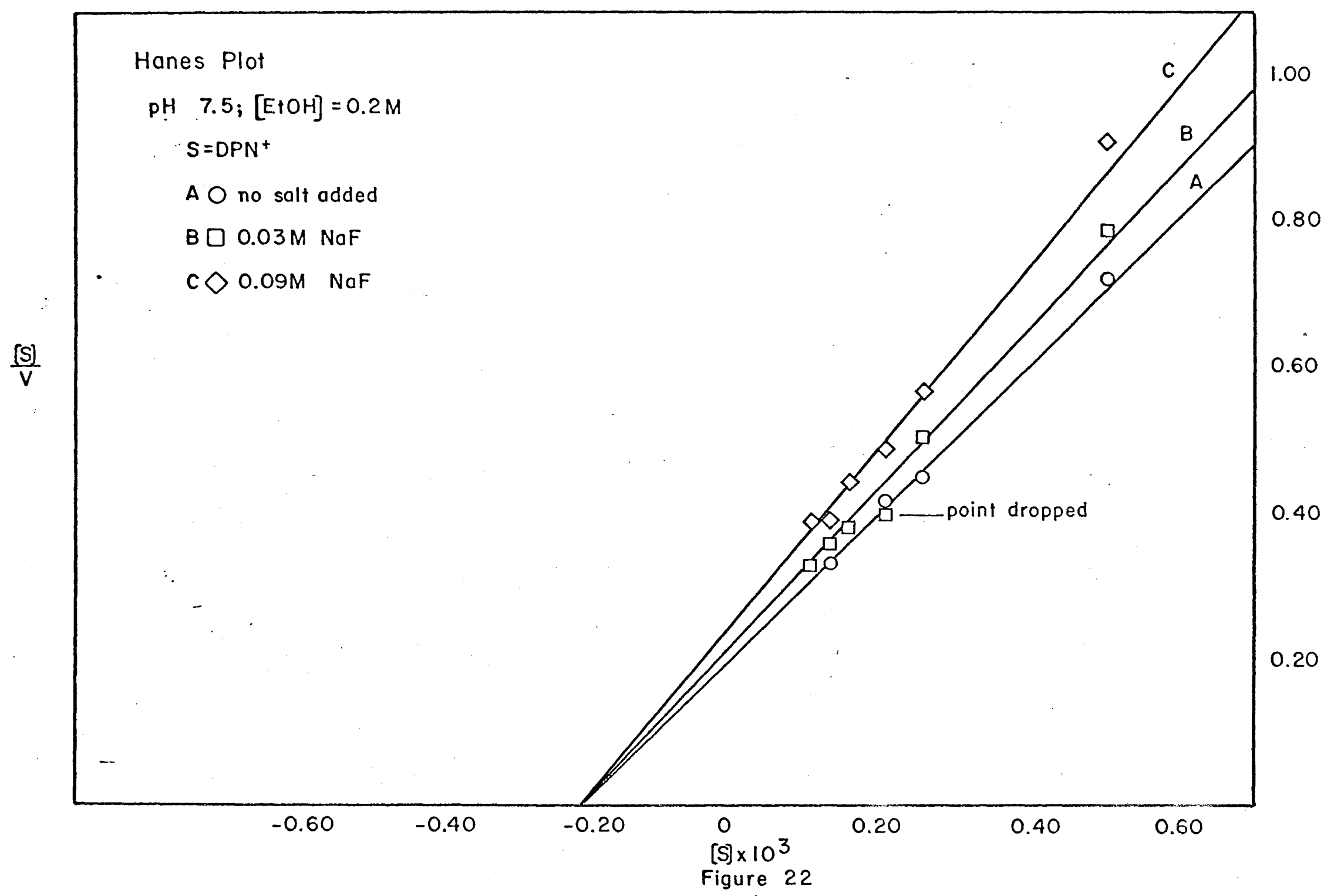




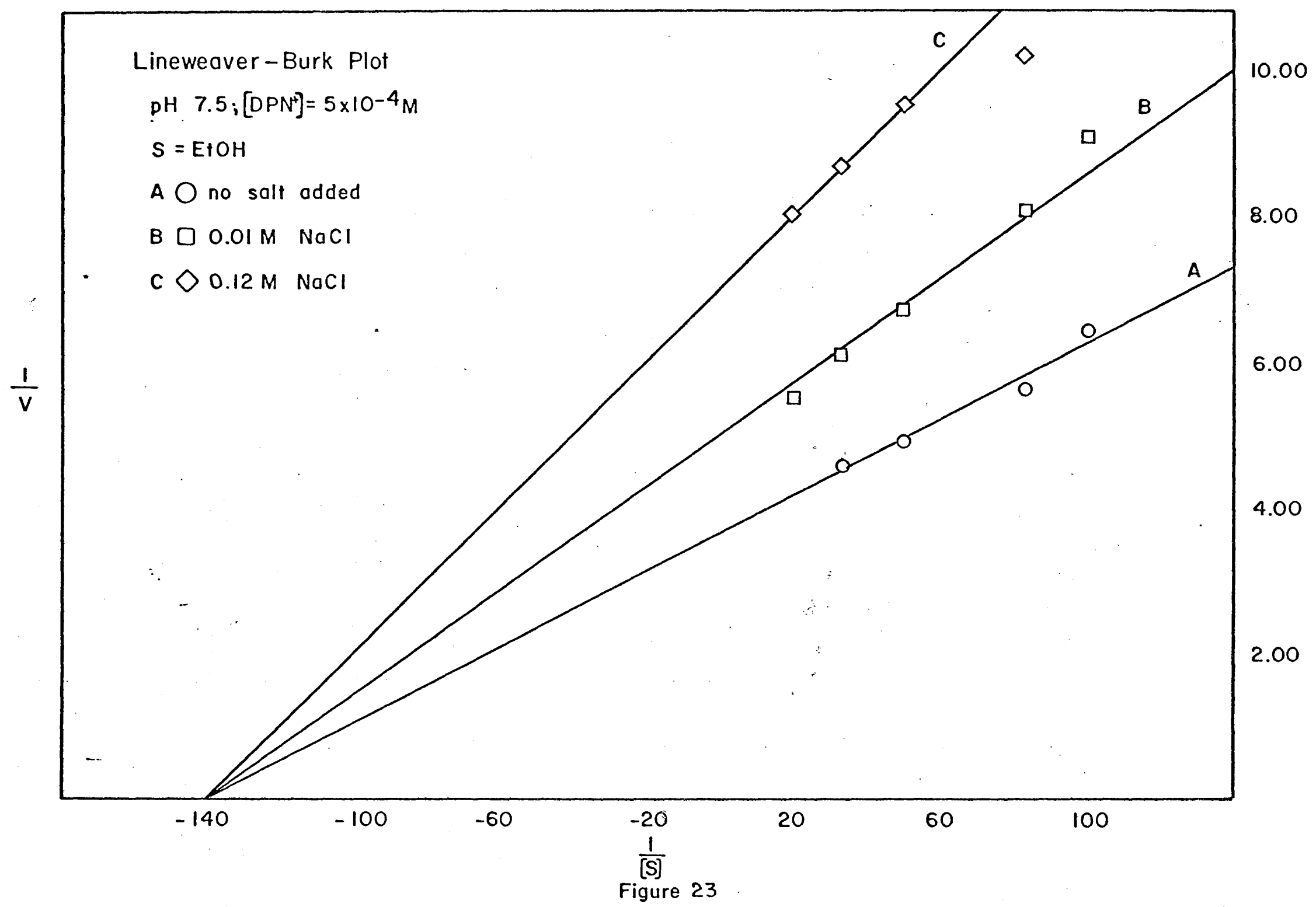




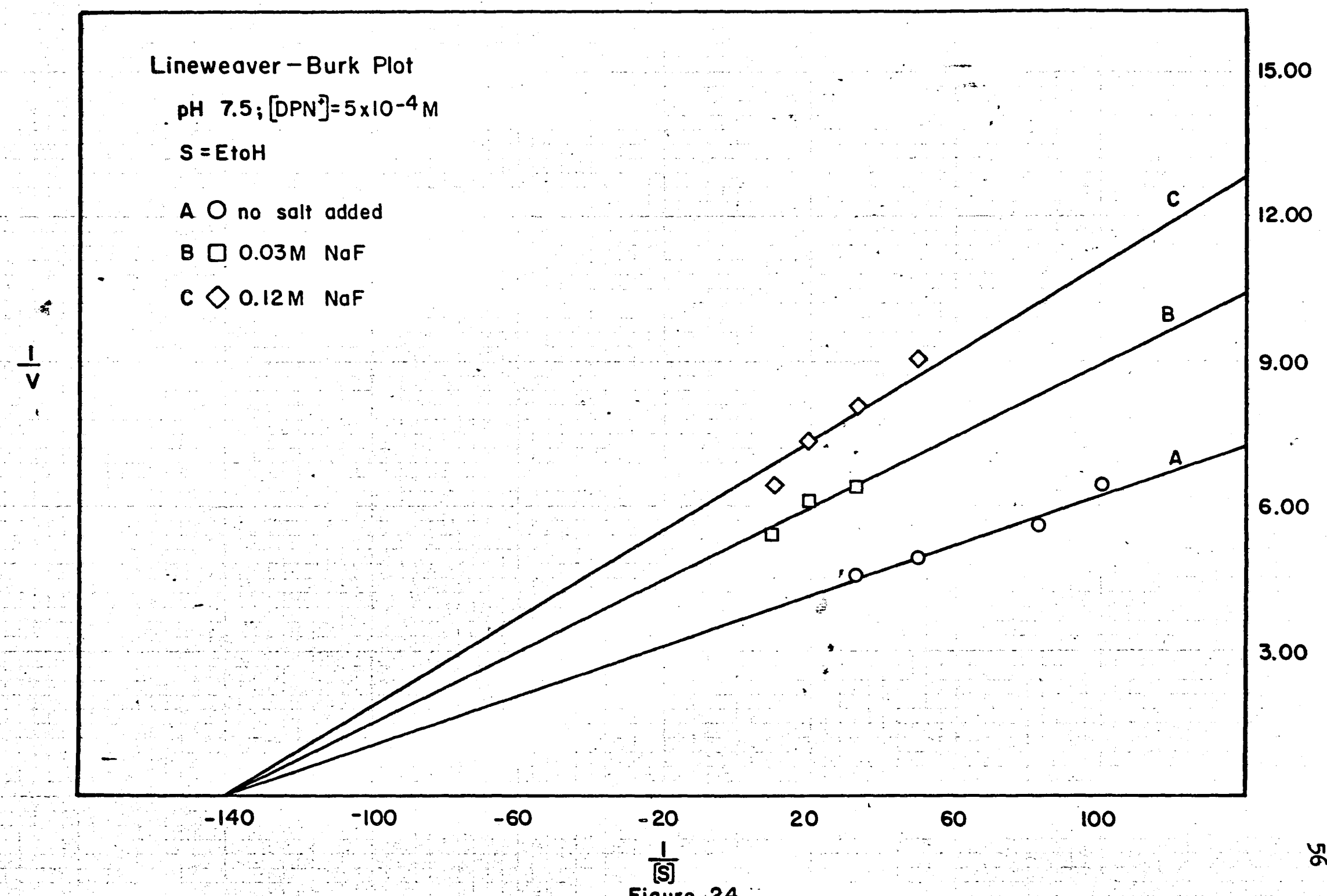

Figure 24 


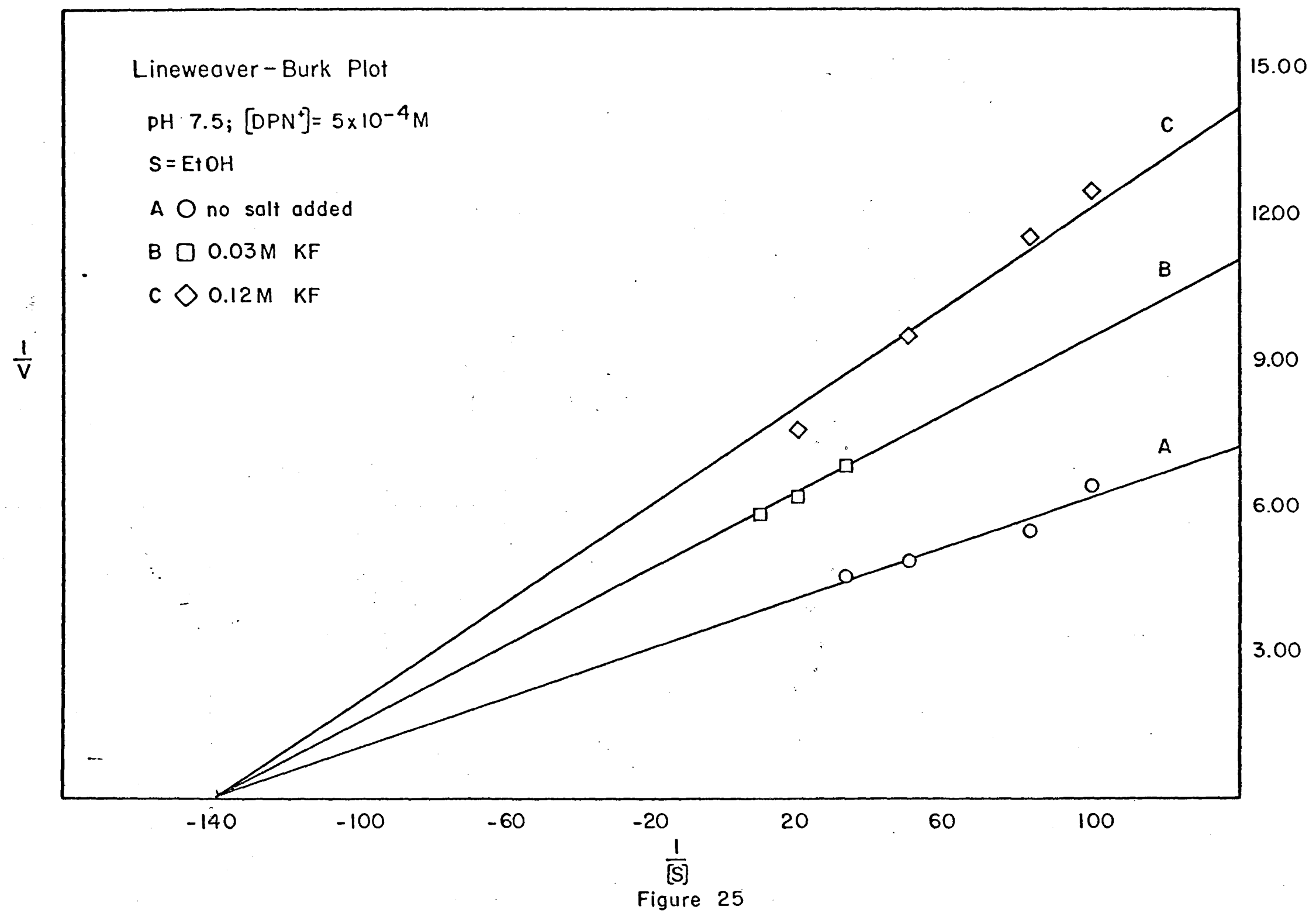




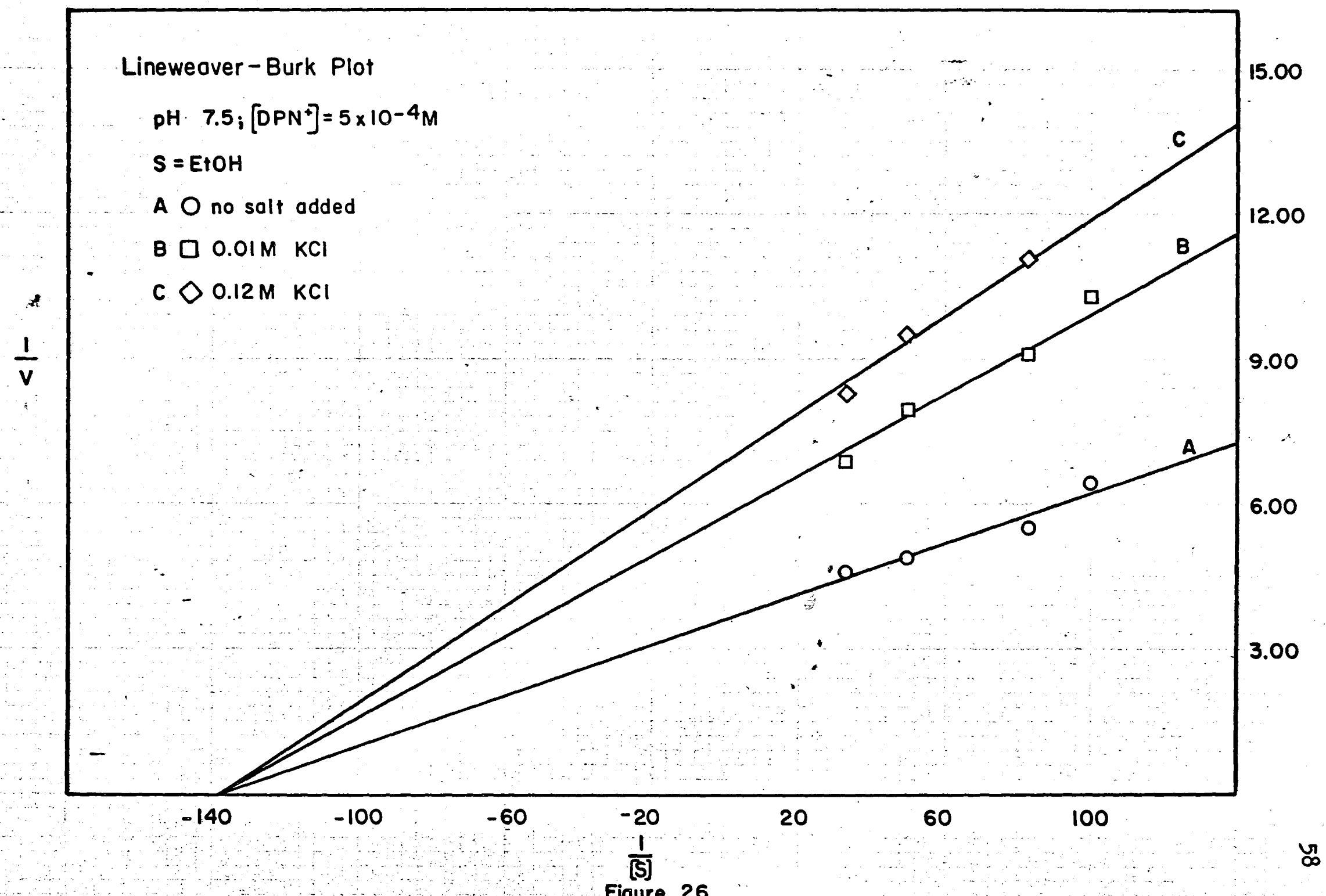

Figure 26 
See graphs 27 through 31.

Since the ionic strength is based on the concentration of ions in solution, it was necessary to calculate the species in solution in the pyrophosphate buffer. This was done using the Henderson-Hasselbalch equation: $\mathrm{pH}=\mathrm{pK}_{\mathrm{a}}+\log \frac{\text { (salt) }}{\text { (acid) }}$. The predominant species in solution in the pyrophosphate buffer were: $\mathrm{P}_{2} \mathrm{O}_{7}^{-4}, \mathrm{HP}_{2} \mathrm{O}_{7}^{-3}, \mathrm{H}_{2} \mathrm{P}_{2} \mathrm{O}_{7}^{-2}$, and $\mathrm{HPO}_{4}^{-2}$. These were then used in the following equation to calculate the ionic strength: $\mu=\frac{\sum c_{i} z_{i}^{2}}{2}$. The pyrophosphate buffer contributes an ionic strength of 0.07 in the reaction mixture at both $\mathrm{pH}$ levels.

\section{Results}

The Lineweaver-Burk plots show that at $\mathrm{pH} 7.5$, the maximal velocity decreases with an increase in salt concentration, while the Michaelis constants remain the same. At $\mathrm{pH} 8.5$, the maximal velocity decreases with an increase in salt concentration when the concentration of ethanol is held constant and the $\mathrm{DPN}^{+}$concentration is varied; and it increases at low salt concentrations, and decreases at high salt concentration when the $\mathrm{DPN}^{+}$concentration is held constant and the ethanol concentration is varied. The $K_{M}$ remains constant for all the salt concentrations.

The average values for the Michaelis constants are:

$\begin{array}{lll}\mathrm{ADH} \cdot \mathrm{DPN}^{+} & \mathrm{pH} 8.5 & 3 \times 10^{-4} \\ & \mathrm{pH} 7.5 & 2 \times 10^{-4} \\ \mathrm{ADH} \cdot \mathrm{EtOH} & \mathrm{pH} 8.5 & 1.5 \times 10^{-2} \\ & \mathrm{pH} 7.5 & 7 \times 10^{-2}\end{array}$




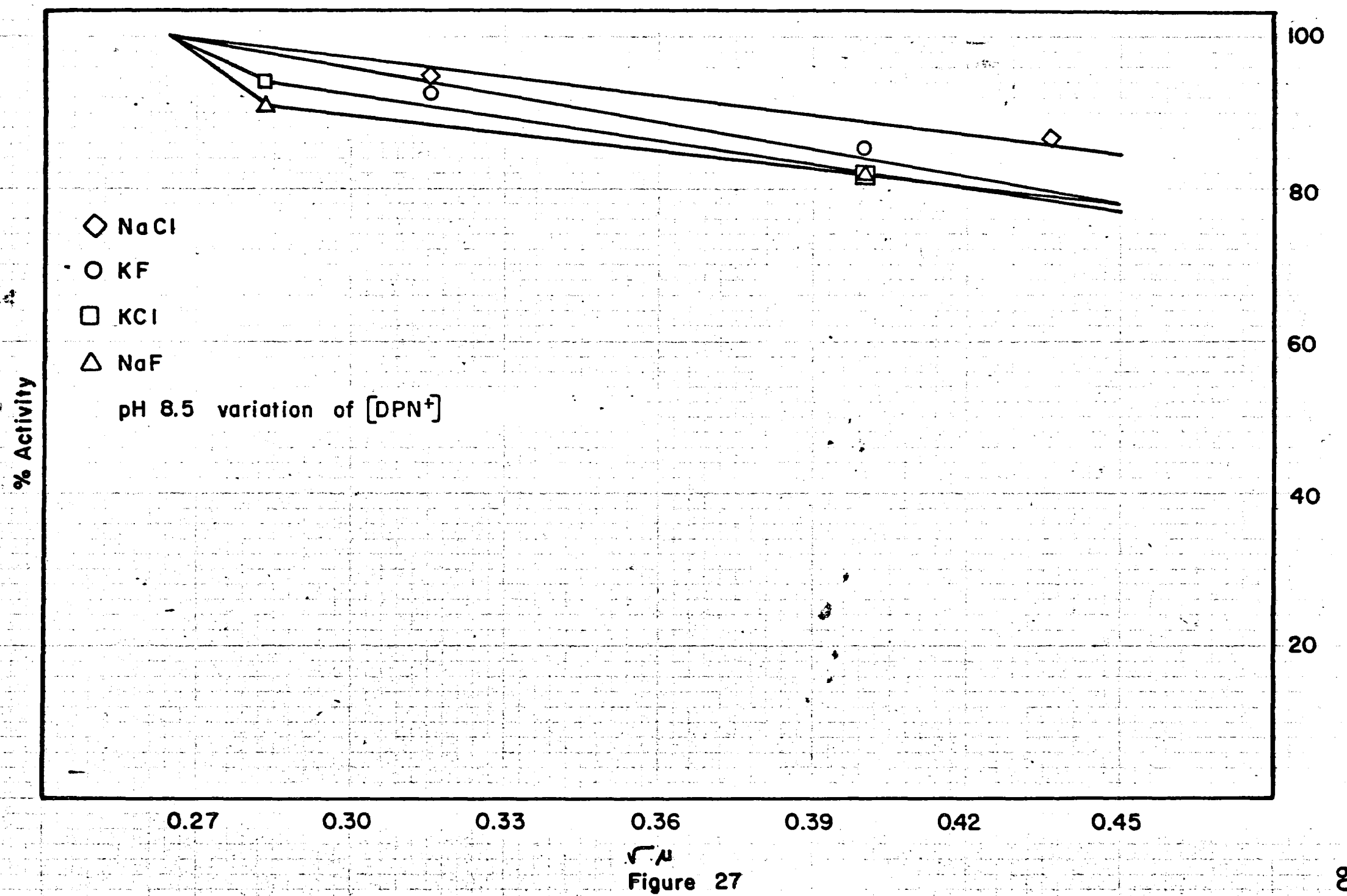




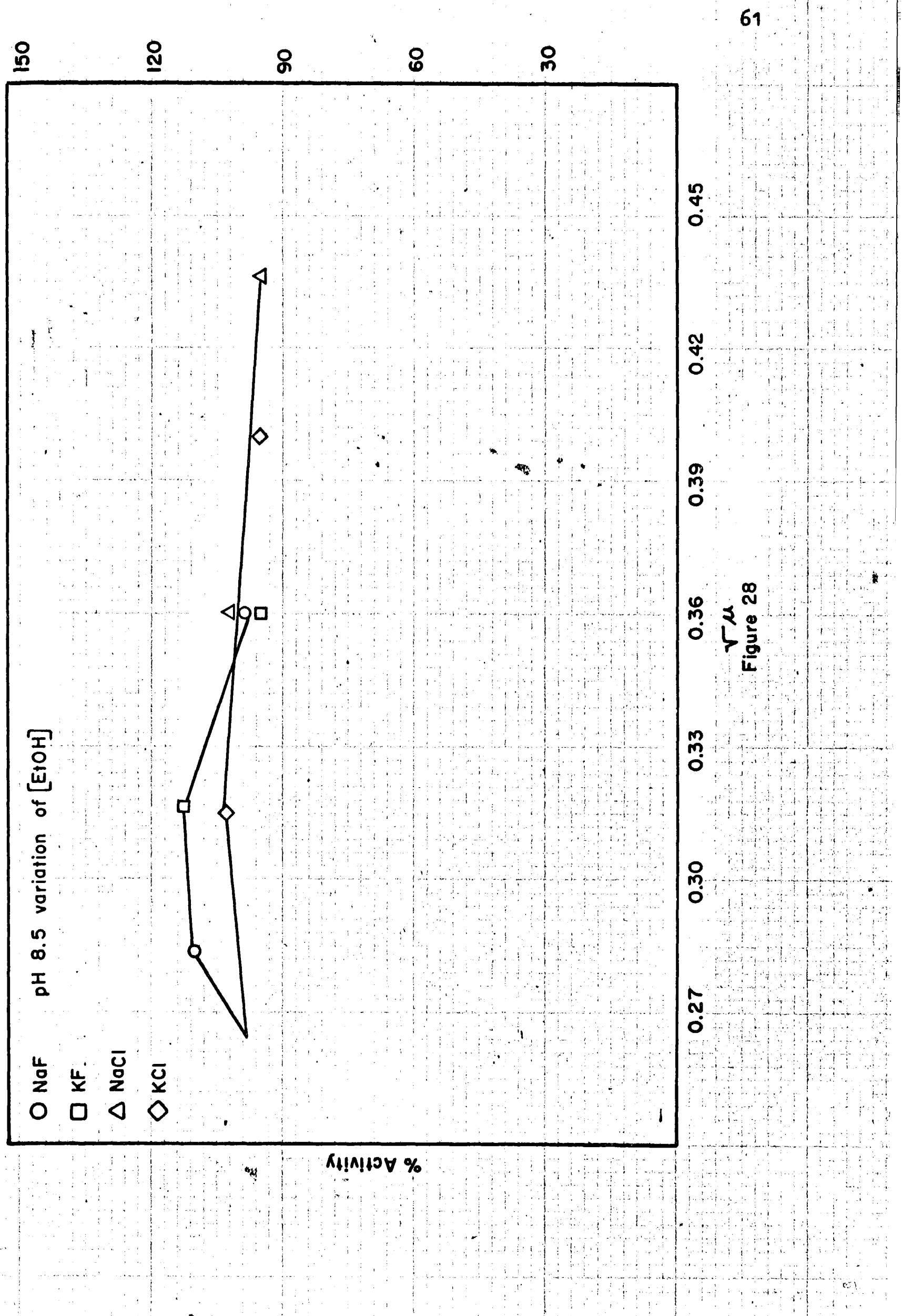




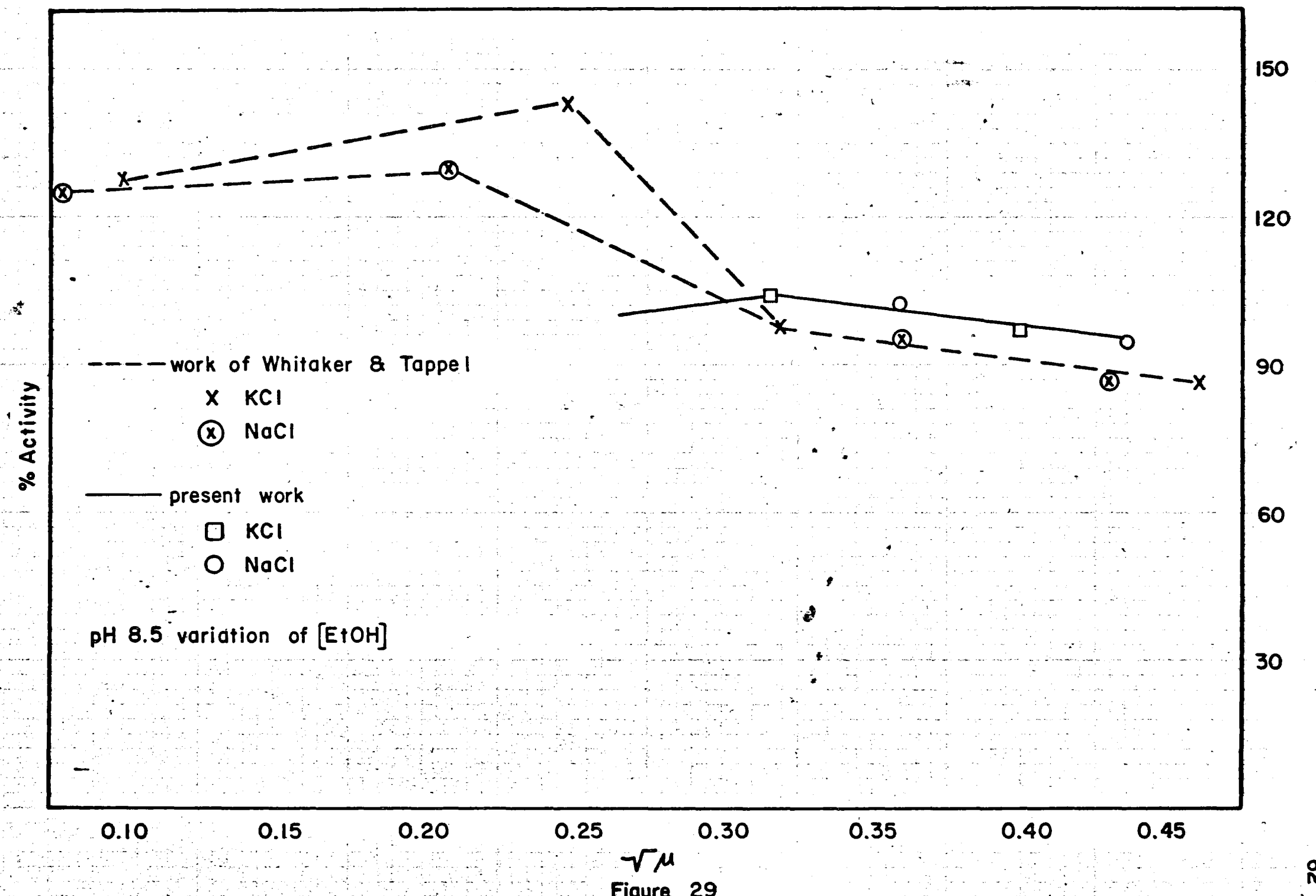




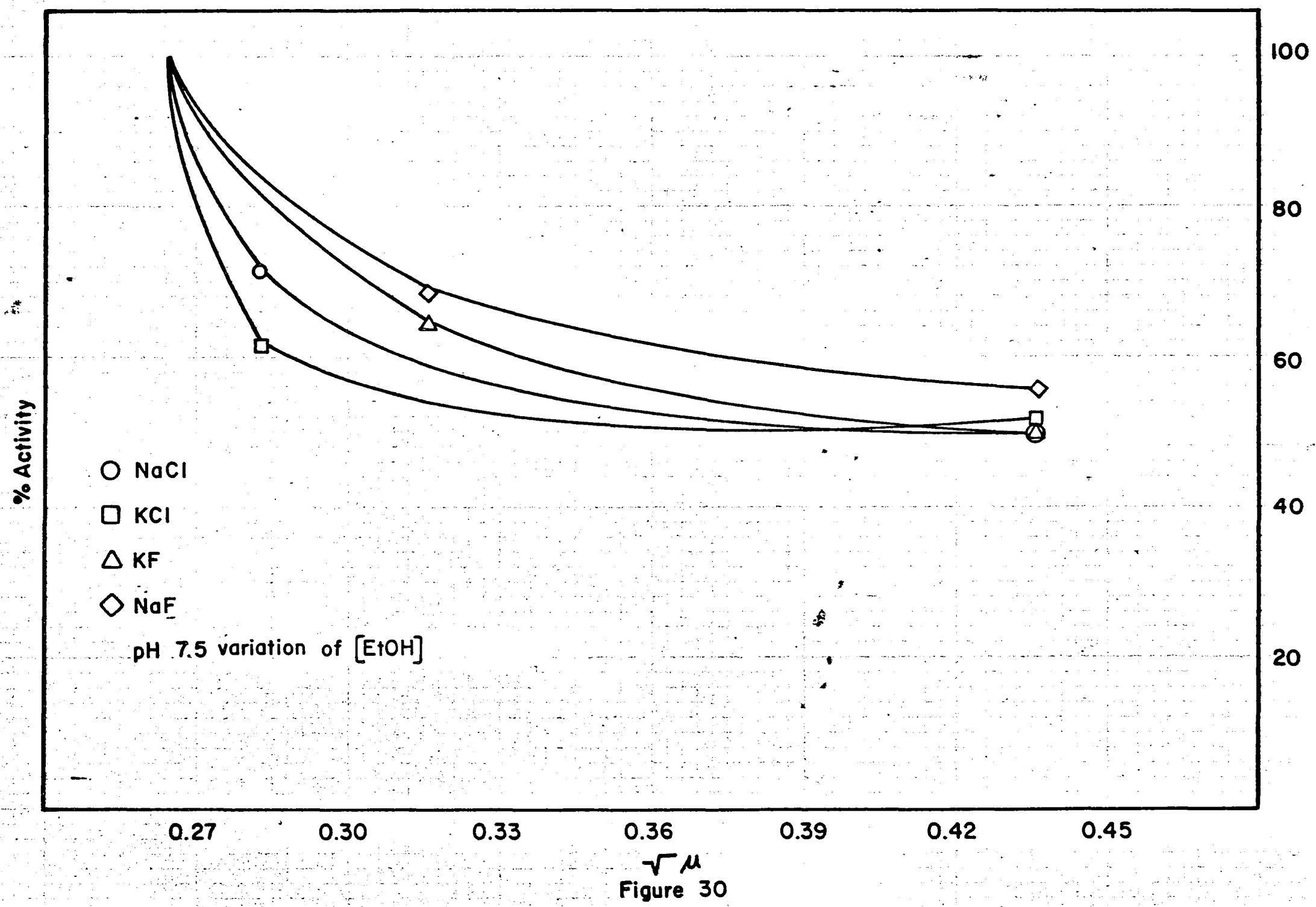




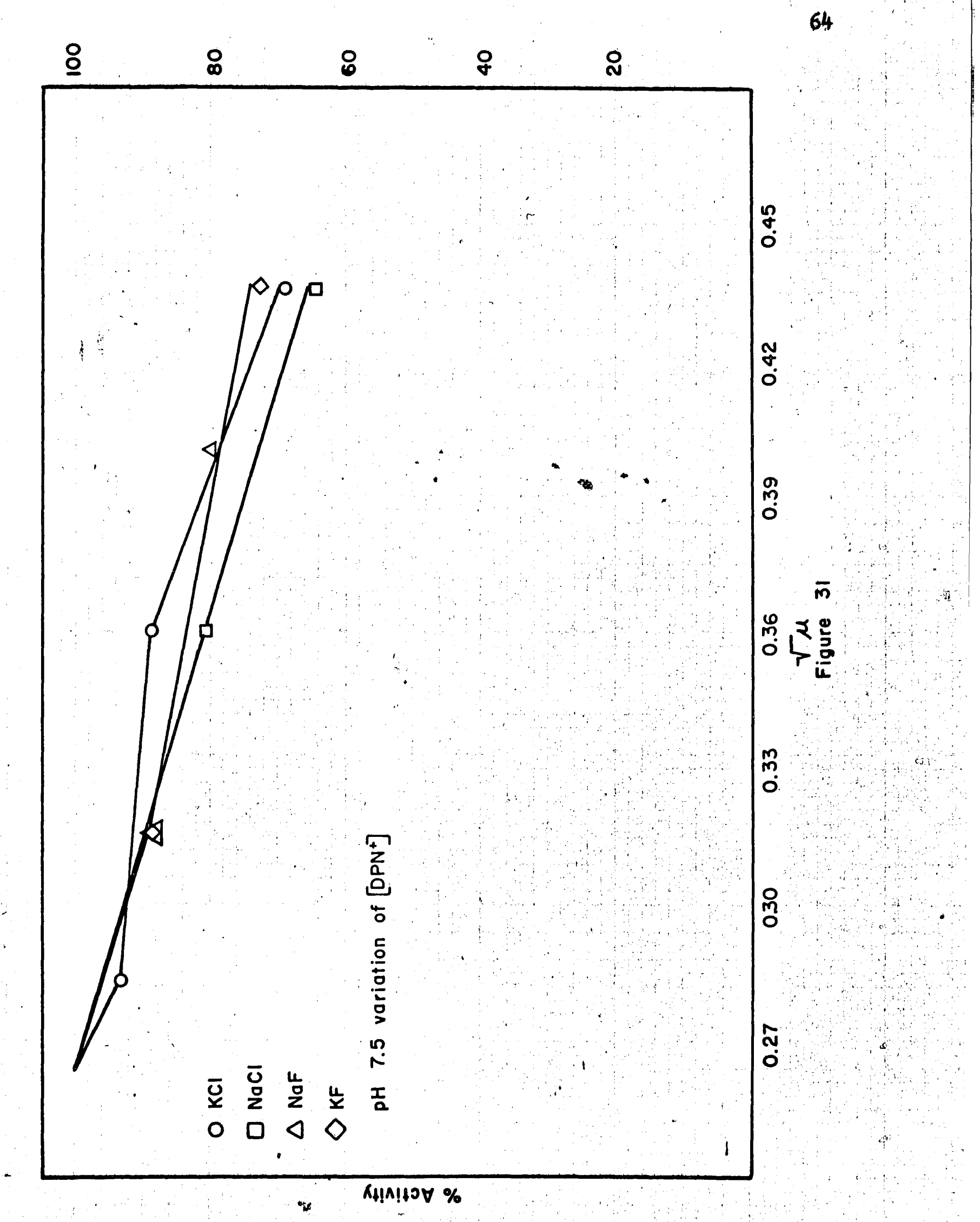


All these values are given for $27^{\circ} \mathrm{C} \pm 0.5^{\circ} \mathrm{C}$. They agree reasonably well with those given in the literature as can be seen by referring to Table IV in the historical background section.

The maximal velocity varies with the different enzyme solutions. Since the maximal velocity changes and the Michaelis constants do not, the inhibition observed is the classical non-competitive type. The inhibition is greater at $\mathrm{pH} 7.5$ than at $\mathrm{pH} 8.5$.

At $\mathrm{pH} 8.5$, the inhibition is very slight regardless of whether the coenzyme concentration or the substrate concentration is being varied. The maximum inhibition is $5 \%$ when the ethanol concentration is varied and $18 \%$ when the $\mathrm{DPN}^{+}$concentration is varied. The maximum activation is $13 \%$ when the ethanol concentration is varied. There is no activation observed with the variance of the $\mathrm{DPN}^{+}$concentration. There is no observable difference between the fluoride and the chloride salts. In the plots of per cent activity vs the $\sqrt{\mu}$ during the variation of the $\mathrm{DPN}^{+}$concentration, $\mathrm{NaCl}$ and $\mathrm{KF}$ show almost a linear relationship between the per cent activity and the $\sqrt{\mu}$. KCl and NaF show a sharper decrease and then level off to almost the same point as $\mathrm{NaCl}$ and $\mathrm{KF}$.

In the plots of per cent activity vs the $\sqrt{\mu}$ during the variation of the ethanol concentration, the chloride salts are essentially the same with both showing some activation at the lower ionic strength. This agrees with the previous work of Whitaker and Tappel (104). In Figure 29, their points can be seen along with the present work. Combining points for the sodium and potassium chloride together, a straight line is formed which parallels the line that Whitaker and Tappel drew combining their data on sodium and potassium chloride. 
At $\mathrm{pH} 7.5$, the inhibition shows a definite difference between the variation of the ethanol concentration and the variation of the $\mathrm{DPN}^{+}$ concentration. With the variation of the $\mathrm{DPN}^{+}$concentration, the maximum inhibition is $34 \%$, and it is $49 \%$ with the variation of the ethanol concentration. There is no observable activation at this $\mathrm{pH}$. The chloride and fluoride salts inhibit to approximately the same extent. The inhibition increases much more rapidly at the lower salt concentrations with the variation of the concentration of ethanol than when the concentration of $\mathrm{DPN}^{+}$is varied. With the variation of the ethanol concentration, the inhibition levels off quite readily after the initial sharp decrease in activity. This can be seen in the plot of the per cent activity vo the $\sqrt{\mu}$ in Figure 30 .

In Figure 31 is shown the plot of the per cent activity vo the for the variation of the $\mathrm{DPN}^{+}$concentration. When the data for sodium and potassium fluoride are combined, they form almost a straight line. $\mathrm{NaCl}$ gives a straight line, and $\mathrm{KCl}$ gives a straight line after a small dip. They all come down to essentially the same percent activity at high salt concentration ( $66 \%$ to $73 \%$ ). 


\section{DISCUSSION}

The oxidation of ethanol by $\mathrm{YADH}$ is inhibited to a very small extent at $\mathrm{pH} 8.5$ by the potassium and sodium salts of chlorine and fluorine. It is essentially the same whether the concentration of ethanol or of $\mathrm{DPN}^{+}$is being varied, $5 \%$ and $18 \%$ respectively. With the variation of the ethanol concentration, a maximum activation of $13 \%$ is observed. This activation is not observed when the $\mathrm{DPN}^{+}$concentration is varied. The activation occurs at low salt concentrations with increasing inhibition occurring as the salt concentration is increased.

The inhibition is almost a linear function of the $\sqrt{\mu}$. It is of the non-competitive type as shown by the constancy of the Michaelis constants and the general decrease in the maximal velocity when these values are determined from the Lineweaver-Burk plots. The inhibition is more a general halide effect than a specific halide effect, since there is no observable difference between the two different halides.

As already shown by Whitaker and Tappel (104), there is no difference between the potassium and sodium salts. The percent inhibition and the type of inhibition are the same for the potassium salts and the sodium salts. It does not appear that the cation has any specific effect on the inhibition. The inhibition may be due to an ionic strength effect, but this cannot be stated definitely from this study since only halide salts were used.

The greatest inhibition observed in this study was at pH 7.5. At this $\mathrm{pH}$, the enzyme is slightly less active than at pH 8.5 (9). At pH 
7.5, when fluoride salts are used, there is a.small amount of HF present. It varies in concentration from $8.94 \times 10^{-8}$ to $1.07 \times 10^{-5} \mathrm{M}$. The observed inhibition cannot be attributed to the presence of this HF, since there is no difference between the chloride and fluoride salts and HCI is known to be $100 \%$ ionized.

The degree of inhibition is much greater when the ethanol concentration is varied than when the $\mathrm{DPN}^{+}$concentration is varied. The ethanol must be exerting some protective effect either by attaching to the active site and reacting with the $\mathrm{DPN}^{+}$or by sterically blocking the $\mathrm{DPN}^{+}$from the ions. The latter of these two possibilities can be ruled out. If the inhibition was based upon reaction of the ions with the $\mathrm{DPN}^{+}$, the degree of inhibition should be greater when the $\mathrm{DPN}^{+}$concentration is varied since the $\mathrm{DPN}^{+}$would not be available in excess and any reduction in the concentration of $\mathrm{DPN}^{+}$would have a greater effect on the rate of reaction.

The order of binding of coenzyme and substrate was discussed in the historical section of this work. It was shown that recent evidence points towards an ordered binding with the coenzyme binding first. It was shown by nmr studies that it was necessary for the coenzyme to bind before the ethanol would bind. This could be interpreted as an allosteric effect by the coenzyme. That is, the coenzyme changes the structure of the enzyme in such a way as to facilitate the binding of the ethanol.

The coenzyme may be functioning in this same way during, the fluoride and chloride ion inhibition. It facilitates the interaction of the anion at or near the binding site of the ethanol by making the 
site more readily available to the ion. By attaching near the site of the ethanol binding, the anion may be interfering by blocking the ethanol binding site without actually binding directly at the ethanol binding site. The attraction of the anion is tighter than the binding of the ethanol, so that even though the ethanol and fluoride ion are competing for the same site, the kinetics are non-competitive. Noncompetitive kinetics are observed whenever an inhibiting species binds at or near either the substrate or the coenzyme site irreversibly. Since the inhibitor binds irreversibly at or near the same site as the substrate, it is seen to have a greater inhibitory effect when the substrate is being varied than when the substrate is held constant at a high concentration. The ethanol binding is less affected by the presence of the ion when it is present in a high concentration than when it is present at a low concentration. 


\section{CONCLUSION}

The higher halide salts of potassium and sodium exhibit a noncompetitive type inhibition with respect to both ethanol and $\mathrm{DPN}^{+}$. The fluoride salts show no greater inhibition than the chloride salts even at $\mathrm{pH} 7.5$, although the per cent of inhibition is greatly increased from that at $\mathrm{pH} 8.5$. This inhibition at $\mathrm{pH} 7.5$ is not due to the presence, of HF. Fluorine containing compounds, toxic in quite small amounts are yet little hydrolyzed to $\mathrm{HF}$ or the fluoride ion. Any effect they may have on this enzyme system cannot be attributed to hydrolysis. 
REFERENCES

1. Iester, D., and Greenberg, I. A. (1950), Arch. Ind. Hyg. and Occup. Med. 2, 30.

2. Roberts, H. L. (1961), Quart. Rev. 15, 30 .

3. Negelein, E., and Wulff, H. J. (1937), Biochem. Z. 289, 436.

4. Racker, E. (1950), J. Biol. Chem. 184, 313.

5. Hayes, J. E., and Velick, S. F., (1954), J. Biol. Chem. 207, 225.

6. Vallee, B. I. (1955), Advan. Protein Chem. 10, 317.

7. Wallenfels, K., and Arens, A. (1960), Biochem. Z. 332, 217.

8. Wallenfels, K., and Sund, H. (1957), Biochem. Z. 329, 17.

9. Keleti, T. (1958), Acta. Physiol. Acad. Sci. Hung. 13, 103.

10. Theorell, H., and Bonnichsen, R. (1951), Acta. Chem. Scand. 5, 1105.

11. Kuff, E. I., Hageboom, G. H., and Striebich, M. J. (1955), J. Biol. Chem. 212, 439.

12. Hageboom, G. H., and Kuff, E. I. (1954), J. Biol. Chem. 210, 733.

13. Sund, H. (1960), Biochem. Z. 333, 205.

14. Jirgensons, B. (1959), Arch. Biochem. Biophys. 85, 532.

15. Jirgensons, B. (1962), Photochem. Photobiol. 1, 59.

16. Negelein, E., and Wulff, H. J. (1937), Biochem. Z. 293, 351. 17. Vallee, B. I., and Hoch, F. I. (1955), Proc. Natl. Acad. Sci. U. S.
41, 327.

18. Wallenfels, K., Sund, H., Zarnitz, M. I., Malhotra, O. P., and Fischer,

J. (1959) in Sulfur in Proteins, Benesch, R., Benesch, R. E., Boyer, P. D., Klotz, I. M., Middlebrook, W. R., Szent-Gyorgi, A. G., and Schwarz, D, R., New York, Academic Press, p. 215.

19. Barron, G., and Levine, S. (1952), Arch Biochem. Biophys. 41, 175.

20. Van Eys, J., and Kaplan, N. O. (1957), J. Amer. Chem. Soc. 79, 2782. 
21. Kagi, J. H. R., and Vallee, B. I. (1960), J. Biol. Chem. 235, 3188.

22. Hoch, F. I., and Vallee, B. L. (1954), J. Biol. Chem. 221, 491.

23. Hoch, F. L., Vallee, B. I., and Williams, R. J. P. (1958), J. Biol. Chem. 232, 453.

24. Wallenfels, K., Sund, H., Faessler, A., and Burchard, W. (1957), Biochem. Z. 329, 31.

25. Boyer, P. D. (1954), J. Amer. Chem. Soc. 76, 4331.

26. Hoch, F. I., and Vallee, B. L. (1959) in Sulfur in Proteins, Benesch, R., Benesch, R. E., Boyer, P. D., Klotz, I. M., Middlebrook, W. R., Szent-Gyorgyi, A. G., and Schwarz, D. R., EdB., New York, Academic Press, p. 245.

27. Whitehead, E. P., and Rabin, B. R. (1964), Biochem J. 90, 532.

28. Harris, J. I. (1964), Nature 203, 30.

29. Nygaard, A. P., and Theorell, H. (1955), Acta. Chem. Scand. 9, 1551.:

30. Aono, Y. (1958), Osaka Diagaku Igaku Zassi 10, 619 (CA 52,15620h).

31. Ebisuzaki, K., and Barron, E. S. G. (1957) Arch. Biochem. Biophys. $69,555$.

32. Gierer, A. (1955), Biochim. Biophys. Acta. 17, 111.

33. Levy, H. R., Loewus, F. A., and Vennesland, B. (1957), J. Amer. Chem. Soc. 79, 2949.

34. Van Eys, J., and Kaplan, N. O. (1957), Biochim. Biophys. Acta. 23, 574.

35. Van Eys, J., Ciotti, M. M., and Kaplan, N. O. (1957), Biochim. BiophyB. Acta. 23, 581.

36. Van Eys, J., Ciotti, M. M., and Kaplan, N. O. (1958), J. Biol. Chem. $231,571$.

37. Anderson, B. M•, Reynolds, M. L., and Anderson, C. D. (1965) Biochim. Biophys. Acta. 99, 46.

38. Anderson, B. M., and Reynolds, M. I. (1965), Biochim. Biophys. Acta. $96,45$.

39. Anderson, B. M., and Anderson, C. D. (1964), Biochem. Biophys. Res. Commun. 16, 258.

40. Anderson, B. M., Reynolds, M. I., and Anderson, C. D. (1966), Biochim. Biophys. Acta. 113, 235. 
41. Anderson, B. M., Reynolds, M. $L^{\circ}$, and Anderson, C. D. (1965), Arch. Biochem. Biophys. 111, 202.

42. Anderson, B. M., and Fonda, M. I. (1967), Arch. Biochem. Biophys. $120,49$.

43. Anderson, B. M., and Reynolds, M. I. (1966), Arch. Biochem. Biophys. $114,299$.

44. Anderson, B. M., and Reynolds, M. I. (1965), Arch. Biochem. Biophys. $111,1$.

45. Vennesland, B., and Westheimer, F. H. (1954), in The Mechanism of Enzyme Action, McElroy, W. D., and Glass, B., Baltimore, John Hopkins Press, p. 357.

46. Hollis, D. P., Bolen, J. I., and Kellum, J. M. (1966), Biochem. Biophys. Res. Commun. 22, 135.

47. Hollis, D. P., (1967), Biochemistry 6, 2080.

48. Jardetzky, O., Wade, N. G., and Fischer, J. J. (1963), Nature 197, 183.

49. Negelein, E., and Wulff, H. J. (1937), Biochem. Z. 289, 436.

50. Alberty, R. A. (1953), J. Amer. Chem. Soc, 75, 1928.

51. Thompson, J. F. (1963) Biochemistry 2; 224.

52. Wratten, C. C., and Cleland, W. W. (1963) Biochemistry 2, 935.

53. Silverstein, E., and Boyer, P. D. (1964), J. Biol. Chem. 239, 3908.

54. Nygaard, A. P., and Theorell, H. (1955), Acta. Chem. Scand. 9, 1300.

55. Dalziel, K. (1963), J. Biol. Chem. 238, 2850.

56. Cleland, W. W. (1963), Biochim. Biophys. Acta. 67, 104.

57. Fisher, H. F., Conn, E. E., Vennesland, B., and Westheimer, F. H., (1953), J. Biol. Chem. 202, 687.

58. Vennesland, B. (1955), Disc. Faraday Soc, 20, 240.

59. Westheimer, F. H., Fisher, H. F., Conn, E..E., and Vennesland, B. (1951), J. Amer. Chem. Soc. 73, 2403.

60. Schellenberg, K. A. (1965), J. Biol. Chem. 240, 1168.

61. Schellenberg, K. A. (1966), J. Biol. Chem. 241, 2446.

62. Palm, D. (1966), Biochem. Biophys. Res. Commun. 22, 151. 
63. Atkinson, M. R., Eckermann, G., and Lilley, R. M. (1967), Biochem. J. 104,872 .

64. Anderson, B. M., Anderson, C. D., Lee, J. K., and Stein, A. M. (1963), Biochemistry 2, 1017.

65. Kaplan, N. O., and Ciotti, M. M. (1953), J. Biol. Chem. 201, 785.

66. Stepanauskas, M., Adrian, B., Hoffman, D., Jacobs, K. A., Nash, P., Schmottlach, B., Walz, I., Weber, R., Scheuch, D., and Rapport, S. (1964), Acta. Biol. Med. Ger. Suppl. 3, 258 (CA 64,23438).

67. Clayton, R. A. (1954), Arch. Biochm. Biophys. 85, 559.

68. Rousch, A. H., and Gowdy, B. B. (1961) Biochim. Biophys. Acta. 52, 200.

69. Neifakh, E. A. (1962), Dokl. Akad. Nauk. SSR 142, 1405 (CA 57,1266f).

70. TappeI, A. I., and Maro, A. G. (1954), J. Agr. Food Chem. 2, 554.

71. Hoch, F. I., Martin, R. G., Wacher, W. E. C., and Vallee, B. L. (1960), Arch. Biochem. Biophys. 91, 166.

72. Duclaux, D. (1960), Biochim. Biophys. Acta. 39, 33 (CA 54,22771d).

73. Duclaux, D. (1964), Biochim. Biophys. Acta. 89, 1. (CA 59, 10409f).

74. Guiditte, A., and Casole, I. (1963), Boll. Soc. Ital. Biol. Sper。 39, 1691 (CA 61,5198d).

75. Guiditte, A., and Casole, I. (1965), Biochim. Biophys. Acta. 110, 17.

76. Masuda, M. (1958), Osaka Daigaku Izaku Zasshi 10, 595 (CA 52,15620d).

77. Rashed, N., and Rabin, B. R. (1968), Eur. J. Biochem. 5, 147 (CA 69,33156h).

78. Okunuki, K., Hagihara, B., Sikuzu, I., Nazaki, M., Yamashito, J., and Yonetani, T. (1955), Symp. Enzyme Chem. 11, 99. (CA 50,14827h)。

79. Sekuzu, I., Hagihara, B., Hattori, F., Shibato; T., Nazaku, M., and Otunsuhi, K. (1957), J. Biochem. (toyko) 44, 587.(CA 52, 1302g).

80. Okunuki, K., Hagihara, B., Sikuzu, I., Nazaku, M., Yamashit, J. and Yonetani, T. (1954), Symp. Enzyme Chem. 10, 143 (CA 49, 14833g).

81. Ohta, T., and Ogura, Y. (1962), Karo Kagahu Shimpozinmu 18, 121 (CA 59,11815c).

82. Wochecker, K. (1957), Biochim. Biophys. Acta. 35, 849. 
83. Hoch, F. I., Williams, R. J. P., and Vallee, B. I. (1958), J. Biol. Chem. $232,465$.

84. Vallee, B. I., Hoch, F. I., Adelstein, S. J., Wacker, W. E. C. (1956), J. Amer. Chem. Soc. 78, 5879.

85. Kawasaki, C. Ichikawa, T., and Kaliye, Y. (1964), Bitamin 30, 299 (CA 62,2976d).

86. Kawasaki, C., Ichikawa, T., and Kaliye, Y. (1966), Bitamin 34, 514. (CA $66,8463 \mathrm{~m})$.

87. Fiddick, R. and Heath, 'H. (1967), Nature 213, 628.

88. Balcavage, W. X., and Mattoon, J. R. (1968), Nature 215, 166.

89. Tschiersch, B. (1966), Tetrahedron Letters 28, 3237.

90. Khouw, L. B., Burbridge, T. N., and Sutherland, V. C. (1963), Biochim. Biophys. Acta. $73,173$.

91. Martoadiprawito, W., and Whitaker, J. R. (1963), Biochim. Biophys. Acta. 77, 536 .

92. Hines, W. J. W., and Smith, M. J. H. (1964), Nature 201, 192.

93. Burke, J. F., and Whitehouse, M. W. (1965), Biochim. Pharm. 14, 1039.

94. Vogel, W., Snyder, R., and Schulman, M. P. (1964), J. Pharmacol. Exptl. Therap. 146, 66.

95. Brighenti, I. (1963), Biochim. Pharmacol 12, 1091.

96. Brighenti, I. (1964), Boll. Chim. Farm. 103, 257 (CA 61, 8575f).

97. Mascoli, P. (1967), Farmacista 22; 138 (CA 67,29427p)

98. Brighenti, I. (1959), Boll. Soc. Ital. Biol. Sper. 35, 560 (CA 55, 15596e).

99. Brighenti, I. (1959), Boll. Soc. Ital. Biol. Sper. 35, 1751 (CA 56, $13238 \mathrm{~b})$.

100. Snodgrass, P. J., Vallee, B. I., and Hoch, F. I. (1960), J. Biol. Chem. 235, 504 .

101. Warburg, 0., and Christian, W., (1941), Biochem. Z. 310, 384.

102. Chaykin, S., (1966'), Biochemistry Laboratory Techniques, New York, John Wiley \& Sons, Inc., p. 18.

103. Dixon, M., and Webb, E. C. (1964), Enzymes, New York, Academic Press, p. 69. 
104. Whitaker, J. R., and Tappel, A. I. (1962), Biochim. Biophys. Acta. 62,310 . 